\title{
Protein Aggregation Patterns Inform about Breast Cancer Response to Antiestrogens and Reveal the RNA Ligase RTCB as Mediator of Acquired Tamoxifen Resistance
}

\author{
Inês Direito ${ }^{1}$, Liliana Monteiro ${ }^{1}{ }^{1}$, Tânia Melo ${ }^{2}$, Daniela Figueira ${ }^{1}$, João Lobo ${ }^{3,4,5}$, , Vera Enes ${ }^{1}$, \\ Gabriela Moura ${ }^{1}$, Rui Henrique ${ }^{3,4,5}$ (D), Manuel A. S. Santos ${ }^{1}$, Carmen Jerónimo ${ }^{3,4,5}{ }^{\circledR}$, Francisco Amado ${ }^{2}$, \\ Margarida Fardilha ${ }^{1}$ (D) and Luisa A. Helguero ${ }^{1, *} *$ (D)
}

Citation: Direito, I.; Monteiro, L.; Melo, T.; Figueira, D.; Lobo, J.; Enes, V.; Moura, G.; Henrique, R.; Santos, M.A.S.; Jerónimo, C.; et al. Protein Aggregation Patterns Inform about Breast Cancer Response to

Antiestrogens and Reveal the RNA Ligase RTCB as Mediator of Acquired Tamoxifen Resistance. Cancers 2021, 13, 3195. https://doi.org/10.3390/ cancers13133195

Academic Editor: Susan Logue

Received: 13 May 2021

Accepted: 18 June 2021

Published: 26 June 2021

Publisher's Note: MDPI stays neutra with regard to jurisdictional claims in published maps and institutional affiliations.

Copyright: (c) 2021 by the authors. Licensee MDPI, Basel, Switzerland. This article is an open access article distributed under the terms and conditions of the Creative Commons Attribution (CC BY) license (https:// creativecommons.org/licenses/by/ $4.0 /)$
1 iBiMED—Institute of Biomedicine, University of Aveiro, 3810-193 Aveiro, Portugal; inesgdireito@ua.pt (I.D.); lilianamonteiro@ua.pt (L.M.); dfdfigueira@live.ua.pt (D.F.); vera.enes@ua.pt (V.E.); gmoura@ua.pt (G.M.); msantos@ua.pt (M.A.S.S.); mfardilha@ua.pt (M.F.)

2 LaQV-REQUIMTE-Associated Laboratory for Green Chemistry of the Network of Chemistry and Technology, University of Aveiro, 3810-193 Aveiro, Portugal; taniamelo@ua.pt (T.M.); famado@ua.pt (F.A.)

3 Department of Pathology, Portuguese Oncology Institute of Porto (IPOP), 4200-072 Porto, Portugal; joaomachadolobo@gmail.com (J.L.); rmhenrique@icbas.up.pt (R.H.); carmenjeronimo@ipoporto.min-saude.pt (C.J.)

4 Cancer Biology and Epigenetics Group, IPO Porto Research Center (GEBC CI-IPOP), Portuguese Oncology Institute of Porto (IPO Porto) \& Porto Comprehensive Cancer Center (P.CCC), 4200-072 Porto, Portugal

5 Department of Pathology and Molecular Immunology, Institute of Biomedical Sciences Abel Salazar, University of Porto (ICBAS-UP), Rua Jorge Viterbo Ferreira 228, 4050-513 Porto, Portugal

* Correspondence: luisa.helguero@ua.pt

Simple Summary: Acquired resistance to antiestrogenic therapy remains the major obstacle to curing luminal subtype breast cancer. While current treatment in acquired endocrine-resistant settings includes combined therapy with receptor tyrosine kinase or cyclin-dependent kinase inhibitors, progression to incurable disease remains possible. In recent years, the antioxidant system and the protein quality control network have been associated with the enhanced resistance of breast cancer cells to hormonal therapy. In this work, we raise the hypothesis that antiestrogen treatment induces the accumulation of protein aggregates in sensitive cells, which in turn could hinder the activation of survival pathways. We present evidence concerning a novel way to identify antiestrogen response and disclose a novel protein, RTBC, that controls acquired antiestrogen resistance. This work opens a new avenue for research towards finding breast cancer prognostic markers and therapeutic targets, where the identification of proteins prone to aggregate could help to identify antiestrogen response and understand mechanisms of disease.

Abstract: The protein quality control network, including autophagy, the proteasome and the unfolded protein response (UPR), is triggered by stress and is overactive in acquired antiestrogen therapy resistance. We show for the first time that the aggresome load correlates with apoptosis and is increased in antiestrogen-sensitive cells compared to endocrine-resistant variants. LC-MS/MS analysis of the aggregated proteins obtained after $4 \mathrm{OH}$-tamoxifen and Fulvestrant treatment identified proteins with essential function in protein quality control in antiestrogen-sensitive cells, but not in resistant variants. These include the UPR modulators RTCB and PDIA6, as well as many proteasome proteins such as PSMC2 and PSMD11. RTCB is a tRNA and XBP1 ligase and its aggregation induced by antiestrogens correlated with impaired XBP1s expression in sensitive cells. Knock down of RTCB was sufficient to restore sensitivity to tamoxifen in endocrine-resistant cells and increased the formation of aggresomes, leading to apoptotic cell death. Analysis of primary human breast cancer samples and their metastases appearing after endocrine treatment showed that RTCB is only localized to aggresomes in the primary tumors, while total aggresomes, including aggregated RTCB, were significantly reduced in the metastases. Therefore, different protein aggregation patterns may indicate loss of function of essential proteins resulting in enhanced protein aggregation that can be used to identify antiestrogen-resistant breast cancer cells and improve the response to antiestrogenic therapy. 
Keywords: breast cancer; estrogen receptors; antiestrogen resistance; protein aggregation; tRNAsplicing ligase RTCB homolog (RTCB)

\section{Introduction}

Development of resistance to endocrine therapy remains the main obstacle for curing estrogen receptor alpha $(\mathrm{ER} \alpha)$-positive breast cancer, with $30-50 \%$ of the patients that initially respond progressing to incurable disease [1,2]. Pre-clinical studies have shown that the unfolded protein response (UPR) and autophagy (AUT) are enhanced, allowing breast cancer resistance to antiestrogen therapy [3-9]. AUT and UPR compensate for therapy-induced stress (i.e., metabolic, oxidative) and mutational load to maintain protein folding and prevent accumulation of toxic protein aggregates [3,10-12]. Disruption of proteostasis to improve anti-cancer therapy has been a topic of increasing research in recent years $[13,14]$.

The UPR is initiated in response to the accumulation of misfolded proteins in the lumen of the endoplasmic reticulum (EnR). Upon BIP releasing itself from the EnR-resident proteins (IRE1 $\alpha$, PERK and ATF6) to bind the misfolded proteins, the EnR-resident proteins initiate the three UPR cascades to restore proteostasis by inhibiting translation and increasing chaperoning and EnR capacity [15]. In breast cancer cells, activation of IRE1 $\alpha$ branch by estrogens leads to an anticipatory response prior to cell division, and is also enhanced in antiestrogen resistance [16]. Initiation of the IRE1 $\alpha$ branch consists of an unconventional cytoplasmic splicing [17], where the IRE1 $\alpha$ endoribonuclease domain removes an intron from the XBP1 mRNA followed by exon ligation by RNA-splicing ligase RtcB homolog (RTCB). The resulting XBP1 mRNA is translated into a functional transcription factor [18] that stimulates the expression of EnR chaperones such as BiP, lipid synthesis and EnR-associated protein degradation (ERAD) [15]. XBP1s is also an estrogen-responsive gene [19]; it can function as an ER $\alpha$ transcriptional co-activator, and upregulation of XBP1s is strongly associated with antiestrogen resistance [4,20]. Inhibition of IRE1 $\alpha$ activity or autophagy can reduce endocrine resistance in breast cancer $[6,21,22]$, supporting the notion that unresolved protein aggregation could enhance drug toxicity.

Toxic protein aggregates have been extensively linked to neurodegenerative diseases $[23,24]$, but their significance has not been followed-up in cancer, with few exceptions, such as mutant p53, which undergoes prion-like aggregation to induce loss of wild-type tumor suppression function [25]. This supports the idea that protein aggregation induced by anti-cancer treatment can engage essential survival proteins, leading to their loss of function. Recently, HDAC6 inhibitors were shown to enhance sensitivity to radiation of breast cancer cell lines by increasing protein aggregation [26]. In this work, we aimed to characterize the aggregated proteome and identify essential proteins needed for endocrine-resistance. We show for the first time, that protein aggregation patterns differ between antiestrogensensitive and -resistant breast cancer cells, with aggregates containing essential proteasome and UPR proteins found exclusively in endocrine-sensitive cells. Specifically, by inhibiting RTCB function, we were able to re-sensitize endocrine-resistant cells to tamoxifen treatment. Therefore, this work opens new avenues for research with the aim of studying the aggregated proteome as a novel approach to improve the response to antiestrogen therapy.

\section{Materials and Methods}

\subsection{Cell Culture}

MDA-MB-231 cells were grown in Dulbecco's modified Eagle's medium (DMEM) supplemented with 10\% FBS and 5\% PEST (Thermo Fisher Scientific, Bremen, Germany). MCF-7 and T-47D were grown in RPMI medium supplemented with $10 \%$ FBS and antibiotics. To obtain tamoxifen resistant cells (MCF-7R and T-47DR), endocrine responsive cells were grown in medium containing $500 \mathrm{nM}$ 4-hydroxytamoxifen (TAM; Sigma-Aldrich, St. Louis, MO, USA) for 8 weeks, after which ER expression and cell number in response 
to TAM and ICI 182780 (ICI; Sigma-Aldrich, St. Louis, MO, USA) were confirmed by cell counting and Western blot and showed to be either unaltered or increased (Supplementary Figure S1). This phenotype was tested every time the cells were thawed. To rule out clonal effects, MCF-7 and MCF-7R cell lines obtained from Dr. Julia Gee at Cardiff University were also used. MCF-7R and T-47DR cells were routinely grown in RPMI medium supplemented with 10\% FBS, $100 \mathrm{nM}$ TAM and antibiotics. All cell lines were grown at $37{ }^{\circ} \mathrm{C}$ in a humidified 5\% CO2/95\% air atmosphere. Twenty-four hours before treatment, the growth medium was replaced by phenol red-free RPMI 1640 or DMEM with 5\% charcoal-treated FBS (DCC), 1\% PEST and supplemented with $4 \mathrm{mM}$ glutamine. ER ligands were dissolved in $100 \%$ ethanol (ETOH) and used at a final test concentration of $10 \mathrm{nM} \mathrm{E2,} 250 \mathrm{nM} \mathrm{ICI}$, or 500 nM TAM. Autophagy inhibitors Bafilomycin (lysosomal inhibitor) or Spautin-1 (USP10 and USP13 inhibitor) were used at a final concentration of $1 \mu \mathrm{M}$ alone or in combination with $500 \mathrm{nM}$ tamoxifen (TAM) for $8 \mathrm{~h}$. MDA-MB-231, T-47D and MCF-7 cell lines were purchased from ATCC and used straight away, all cell lines were routinely checked for mycoplasma infection using PCR.

\subsection{Cell Proliferation and Transfection Assays}

The cells were plated in 24 -well culture plates $\left(5 \times 10^{4}\right.$ cells $\left./ \mathrm{mL}\right)$ in phenol red-free medium with 5\% DCC. On day 1 after plating, cells were treated with the different study conditions in triplicate. On day 2 and day 3, medium was renewed, and on day 5 each well was treated with trypsin and cells were counted using a Neubauer chamber. For small interfering RNA (siRNA)-mediated knockdown of RTCB, cells were transfected with $1 \mathrm{nM}$ of either the targeting siRNA (RTCBi) or a control (RTCBc) sequence (Sigma-Aldrich) using HiPerFect (Qiagen, Hilden, Germany) or Lipofectamine RNAiMAX (Invitrogen, Carlsbad, CA, USA) for $24 \mathrm{~h}$. For cell proliferation assays, cells were treated with TAM [500 nM] or equivalent volume of solvent (ETOH) for $72 \mathrm{~h}$. For Western-blot hybridization or CASP-3 activity experiments cells were treated with $4 \mu 8 \mathrm{C}(25 \mu \mathrm{M})$, Thapsigargin (Acros Organic, Geel, Belgium) $(0.5 \mu \mathrm{M})$, TAM (500 nM) or equivalent volume of solvent (ETOH) for $3 \mathrm{~h}$ and $24 \mathrm{~h}$, respectively.

\subsection{Insoluble Protein Isolation}

Cells were harvested in ELB lysis buffer (0.5\% Triton-X100; 5\% HEPES $1 \mathrm{M}$ pH 7; 5\% NaCl 5 M; 0.1\% DTT 1 M; 0.1\% NaF 1 M; 1\% EGTA 0.1 M pH8; 0.4\% EDTA 0.5 M; 1\% Na3VO4 (all from Sigma-Aldrich); 2\% Protease inhibitor 50× (Roche, Mannheim, Germany); 2.5\% PMSF (Thermo Fisher Scientific, Bremen, Germany); H2O miliQ), and kept on ice while total protein was measured using a standard BSA assay. For insoluble protein fraction isolation $100 \mu \mathrm{g}$ of total protein were diluted in $100 \mu \mathrm{L}$ ELB buffer and centrifuged at $16,000 \mathrm{G}$ for $20 \mathrm{~min}, 4^{\circ} \mathrm{C}$. The supernatant was discarded, and the pellet was resuspended in $80 \mu \mathrm{L}$ ELB buffer $+20 \mu \mathrm{L}$ NP40 (Thermo Fisher Scientific). After sonication, the solution was centrifuged at $16,000 \mathrm{G}$ for $20 \mathrm{~min}, 4{ }^{\circ} \mathrm{C}$. The supernatant was discarded. For SDS-Page electrophoresis, the pellet was resuspended in $50 \mu \mathrm{L}$ ELB buffer, and for Western blot hybridization the pellet was resuspended in $20 \mu \mathrm{L}$ ELB buffer and a sonication step was performed. The total protein and insoluble protein extracts were stored at $-80{ }^{\circ} \mathrm{C}$ until use.

\subsection{SDS-PAGE Electrophoresis and Western Blot Hybridization}

Proteins were denatured for $5 \mathrm{~min}$ at $95^{\circ} \mathrm{C}$ in $6 \times$ SDS loading buffer $(375 \mathrm{mM}$ Tris$\mathrm{HCl}$; 9\% SDS (Sigma Aldrich); 50\% Glycerol; 0.03\% Bromophenol blue (Thermo Fisher Scientific)). Twenty $\mu \mathrm{g}$ of total protein or $25 \mu \mathrm{L}$ of insoluble protein were resolved by $7.5 \%, 10 \%$ or $12 \%$ SDS-PAGE. Thereafter, the bands were either visualized with Coomassie blue or transferred onto nitrocellulose membranes (Amersham, Darmstadt, Germany). Membranes were blocked with a solution of 5\% BSA in $0.05 \%$ Tween-TBS and incubated overnight with the following primary antibodies: anti-ER $\alpha$ (sc-373863) 1:300, $\beta$-amyloid (sc-28365) 1:500, SQSTM1 (sc-28359) 1:1000, LC3 $\alpha / \beta$ (sc-398822) 1:800, XBP1 (sc-8015) 
1:500, IRE1 $\alpha$ (sc-390960) 1:500, PSMC2 (sc-166972) 1:500, PSMD11 (sc-517422) 1:500, PDIA6 (sc-365260) 1:500, all from Santa Cruz Biotechnology; RTCB (HPA000535, Sigma-Aldrich); Ubiquitin (GT7S1) 1:1000, GeneTex (Irvine, CA, USA); BIP (\#3183) 1:800, PERK (\#5683) 1:800, p-PERK (\#3179) 1:800, Eif2 $\alpha$ (\#5324) 1:800 and p- Eif2 $\alpha$ (\#3597) 1:800, all from Cell Signalling Technology (Danvers, MA, USA). Immunoreactive products were visualized by chemiluminescence with a Bio-Rad ChemiDoc ${ }^{\mathrm{TM}}$ Imager or fluorescence with a LI-COR Odyssey 9120 Digital Imaging System. Protein loading was visualized by Ponceau staining. Band intensity quantification was performed by densitometry using the ImageLab digital densitometry software freely available for download from Biorad. For Western blots, band intensity was normalized using the Ponceau intensity of the whole lane. XBP-1s/XBP$1 \mathrm{u}$ ratio was calculated by dividing the intensity of both bands in the same membrane followed by ponceau normalization of the lane. Densitometry values of total lysates were first standardized using ponceau staining intensity and then used to normalize the insoluble protein levels. Intensity was compared between treatments of the same cell line. The graphs show relative changes compared to the untreated control in MCF-7 or T-47D cells.

\subsection{Aggresome Detection and Co-Localization Studies}

ProteoStat $^{\circledR}$ Aggresome Detection Kit Assay (Enzo Life Sciences, Farmingdale, NY, USA) was used for detection of protein aggregates in cells and tissues. ProteoStat ${ }^{\circledR}$ is a $488 \mathrm{~nm}$ excitable fluorescent molecular probe which is like Thioflavin-T, a rotor moleculedye that is essentially nonfluorescent until it binds to structural features associated with aggregated proteins [27]. All procedures using the ProteoStat ${ }^{\circledR}$ Aggresome Detection Kit were conducted according to the manufacturer's instructions using a positive control for protein aggregation that consisted of the same cells treated with the proteasome inhibitor MG132 run in parallel. Briefly, after cell fixation and permeabilization, unspecific dye binding was blocked with 10\% FBS, $0.5 \%$ Triton X-100 in PBS for $1 \mathrm{~h}$. Quantification of \# of cells with protein aggregates (PA)/total \# of cells was carried out in 3 independent experiments in which 6 to 8 random field images at $200 \times$ magnification were taken of each treatment (at least 10,000 cells per group were counted). Fluorescence microscopy was carried out in a Zeiss Axio Imager Z1 microscope (Zeiss, Oberkochen, Germany) equipped with a CCD monochromatic digital camera (Axiocam HRm) or in an Olympus IX-81 microscope (Olympus, Tokyo, Japan) equipped with a CCD monochromatic digital camera (F-view II). ImageJ digital open source software was used to calculate the numbers of positive stained cells and to measure the parameter correlated fluorescence [CF = fluorescence intensity(area $x$ mean fluorescence intensity of background]. For co-localization studies, ProteoStat ${ }^{\circledR}$ [1:1000] was incubated for $30 \mathrm{~min}$ at room temperature (RT) with CellEventTMCaspase-3/7 Green (Invitrogen, Carlsbad, CA, USA), according to manufacturer's instructions, or with the following antibodies: SQSTM1 (sc-28359, Santa Cruz Biotechnology) 1:500, LC3 $\alpha / \beta$ (sc-398822, Santa Cruz Biotechnology) 1:500, $\beta$-amyloid 1:400 or RTCB 1:200, incubated overnight at $4{ }^{\circ} \mathrm{C}$. Fluorescence confocal microscopy was carried out in a Zeiss LSM-510 META confocal microscope (Zeiss, Oberkochen, Germany) or in a Zeiss LSM 880 confocal microscope with Airyscan.

\subsection{Tryptic Digestion, Mass Spectrometry Analysis and Protein Identification}

Tryptic digestion was performed according to [28], with a few modifications. Protein bands were manually excised from the gel and transferred to $1.5 \mathrm{~mL}$ plastic tubes. The gel pieces were washed one time with $25 \mathrm{mM}$ ammonium bicarbonate, three times with $25 \mathrm{mM}$ ammonium bicarbonate/50\% acetonitrile (ACN, VWR Chemicals, Radnor, PA, USA) and one time with ACN. The protein's cysteine residues were reduced with $10 \mathrm{mM}$ DTT ( $45 \mathrm{~min}$ at $56^{\circ} \mathrm{C}$ ) and alkylated with $55 \mathrm{mM}$ iodo-acetamide (30 min at RT). The gel pieces were washed with $25 \mathrm{mM}$ ammonium bicarbonate, followed by $25 \mathrm{mM}$ ammonium bicarbonate $/ 50 \%$ ACN and finally with ACN. Gel pieces were dried in a SpeedVac (Savant, Thermo Fisher Scientific, Bremen, Germany) and rehydrated in digestion buffer containing 
$12.5 \mu \mathrm{g} / \mathrm{mL}$ sequencing grade modified trypsin (AbSCIEX) in $50 \mathrm{mM}$ ammonium bicarbonate. After $30 \mathrm{~min}$ at $37^{\circ} \mathrm{C}$, the supernatant was removed and discarded, $50 \mu \mathrm{L}$ of $50 \mathrm{mM}$ ammonium bicarbonate were added and the samples were incubated overnight (for $16 \mathrm{~h}$ ) at $37{ }^{\circ} \mathrm{C}$. Extraction of tryptic peptides was performed by the addition of $5 \%$ formic acid (FA, Fluka, Mexico City, MX, USA) one time and 5\% FA/50\% CAN, twice. Tryptic peptides were lyophilized in a SpeedVac (Savant, Thermo Fisher Scientific, Bremen, Germany) and resuspended in 1\% FA solution. The samples were analyzed with a Q Exactive Hybrid Quadrupole-Orbitrap (Thermo Fisher Scientific, Bremen, Germany) through the EASYspray nano ESI source (Thermo Fisher Scientific, Bremen, Germany) that was coupled to an Ultimate 3000 (Dionex, Sunnyvale, CA, USA) nano HPLC (high-pressure liquid chromatography) system. The trap (5 mm $\times 300 \mu \mathrm{m}$ I.d.) and the EASY-spray analytical $(150 \mathrm{~mm} \times 75 \mu \mathrm{m})$ columns used were C18 Pepmap100 (Dionex, LC Packings) with a particle size of $3 \mu \mathrm{m}$. Peptides were trapped at $30 \mu \mathrm{L} / \mathrm{min}$ in $96 \%$ solvent A $(0.1 \%$ FA). Elution was achieved with the solvent $\mathrm{B}(0.1 \%$ formic acid $/ 80 \%$ acetonitrile $v / v)$ at $300 \mathrm{~nL} / \mathrm{min}$. The 92 min gradient used was as follows: 0-3 min, 4\% solvent B; 3-70 min, 4-25\% solvent B; 70-90 min, 25-40\% solvent B; 90-92 min, 40-90\% solvent B; 92-100 min, 90\% solvent B; 100-101 $\mathrm{min}, 90-4 \%$ B, 101-120 min, 4\% solvent B. The mass spectrometer was operated at $2.2 \mathrm{kV}$ in the data dependent acquisition mode. A MS2 method was used with a FT survey scan from 400 to $1600 \mathrm{~m} / \mathrm{z}$ (resolution 70,000; AGC target 1E6). The 10 most intense peaks were subjected to HCD fragmentation (resolution 17,500; AGC target 5E4, NCE 28\%, max. injection time $100 \mathrm{~ms}$, dynamic exclusion $35 \mathrm{~s}$ ). Spectra were processed and analyzed using Proteome Discoverer (version 2.2, Thermo Fisher Scientific, Bremen, Germany), with the MS Amanda (version 2.0, University of Applied Sciences Upper Austria, Research Institute of Molecular Pathology, Vienna, Austria) and Sequest HT search engines. Uniprot (TrEMBL and Swiss-Prot) protein sequence database (version of May 2017) was used for all searches under Homo Sapiens. Database search parameters were as follows: carbamidomethylation of cysteine, oxidation of methionine, and the allowance for up to two missed tryptic cleavages. The peptide mass tolerance was $10 \mathrm{ppm}$, and fragment ion mass tolerance was $0.02 \mathrm{Da}$. To achieve a 1\% false discovery rate, the Percolator (version 2.0, Thermo Fisher Scientific, Bremen, Germany) node was implemented for a decoy database search strategy, peptides were filtered for high confidence and a minimum length of 6 amino acids and proteins were filtered for a minimum number of 1 peptide sequence. Only proteins with mean values above $25 \%$ vs. control (ETOH) condition were considered as upregulated in the insoluble fraction.

\subsection{Statistical Analysis and Bioinformatics}

Statistical analysis was performed using GraphPad Prism software version 6.0. Data from at least two independent experiments were used to calculate the mean \pm standard deviation (SD). Mann-Whitney tests were used for the comparison of two independent groups for immunofluorescence, Western blotting, cell proliferation and siRNA assays. Wilcoxon tests were used for analysis of human breast cancer paired tissue samples. Differences were considered significant if $p<0.05$. Venny 2.1 [29] was used to identify the upregulated proteins uniquely found in MCF-7 cells treated with TAM or ICI. For this, first up-regulated proteins in each treatment were obtained by comparison to the control $(\mathrm{ETOH})$, second the upregulated proteins by E2 were deleted from the list, and finally up-regulated proteins by the antiestrogens in MCF-7 were compared to those found in MCF-7R cells.

\subsection{Patient Sample Collection and Characterization}

The clinicopathological data of the patient cohort are presented in Supplementary Table S1. The samples used in this study are within the project "Exploring epigenetic profiling as prognostic/predictive markers of endocrine resistance in estrogen receptor positive breast cancer" approved by IPO Porto's Ethical Committee (CES IPO: 369/2017). 


\section{Results}

3.1. Aggresome Accumulation Correlates with Reduced UPR and Autophagy Activation in Antiestrogen-Sensitive Breast Cancer Cells

In antiestrogen-resistant (MCF-7R) cells, the XBP-1s/XBP-1u ratio increased already after $3 \mathrm{~h}$ incubation with TAM or ICI and increased throughout the $12 \mathrm{~h}$ evaluated, while in MCF-7 cells it did not significantly change (Figure 1A). We ruled out the possibility that MCF-7 cells could be partially compensating EnR stress by activation of the PERK/EIF2A pathway, since neither the ratio p-PERK/PERK nor p-EIF2A/EIF2A increased following TAM or ICI treatment (Figure 1A). To exclude the possibility that E2 could influence the effect of the antiestrogens alone, we carried out a control experiment co-incubating the cells with TAM + E2 and observed the same effects as with TAM alone (Supplementary Figure S3A). Therefore, the model of antiestogen resistance used herein shows efficient activation of the IRE1 $\alpha / \mathrm{XBP} 1$ branch in response to antiestrogens, in line with other studies $[4,6]$.

The lack of UPR activation by MCF-7 cells in response to antiestrogens alone or combined with E2 resulted in protein aggregation and a significant increase in the aggresome levels as well as the \% of cells containing aggresomes (Figure 1B,C and Supplementary Figure S3B). Once again, co-incubation of E2 + TAM produced the same effect as TAM alone. This was also observed in T-47D cells, but not in MCF-7R or T-47DR cells. Treatment with E2, and antiestrogenic treatment in cells which do not express ER $\alpha$ (MDA-MB-231 cells) did not produce aggresome accumulation (Figure 1B,C). This indicates that aggresomes result from antagonizing ER $\alpha$ function in cells that are sensitive to ICI and TAM. The aggresomes were found mostly dispersed in the cytoplasm of sensitive cells, indicating that the protein quality control (PQC) mechanisms were saturated [30], but in MCF-7R and T47-DR cells they were preferably found at the juxtanuclear quality control region that concentrates proteasomes and disaggregating chaperones [31,32], suggesting a functional PQC (Figure 1B,C and Supplementary Figure S3B,C, arrowheads).

Aggresomes are preferably cleared by autophagy [33]; differences in autophagic patterns between MCF-7 and MCF-7R cells were evident already in basal conditions and were maintained after exposure to antiestrogens, with MCF-7R cells showing clear p62 and LC3II puncta colocalization with aggresomes (Supplementary Figure S4A). On the other hand, in MCF-7 the number of puncta was lower, with a more diffuse p62 and LC3-II staining and higher number of aggresomes that did not colocalize (Supplementary Figure S4A). These results are compatible with lower autophagic efficiency in antiestrogen sensitive cells as compared to resistant ones. This is in agreement with the literature $[7,34]$ and the lack of increase in XBP-1s [4], as shown in Figure 1A. It has previously been shown that cyto-protective autophagy can contribute to antiestrogen resistance $[7,8,22,35,36]$, and several groups have shown that inhibition of autophagy can re-sensitize ER $\alpha+$ cells to antiestrogen treatment [7-9,22,34,37-39]. Moreover, co-incubation of MCF-7R cells with TAM and the autophagy inhibitors bafilomycin or spautin- 1 for $24 \mathrm{~h}$ increased the aggresome load and their co-localization with LC-3 or p62 (Supplementary Figure S4B), supporting the notion that enhanced autophagy protects the cells from aggresome accumulation. Aggresome-associated cell death results from toxic gain of function by facilitating aberrant protein-protein interactions [40], or loss of function of essential proteins [41]. Sensitive and resistant cells showed nearly complete aggresomes colocalization with cleaved caspase 3 (cCASP-3) after antiestrogen treatment (not shown); consequently, the number of cells positive for aggresome/cCASP-3 colocalization was significantly higher in antiestrogen-treated MCF-7 and T-47D cells (Figure 1D).

In summary, resistant cells are more capable of clearing protein aggregates that result from antiestrogen treatment because they maintain XBP1s expression and have more efficient autophagy; while in sensitive cells, the lack of aggresome clearance correlates with antiestrogen-induced cell death. 
A
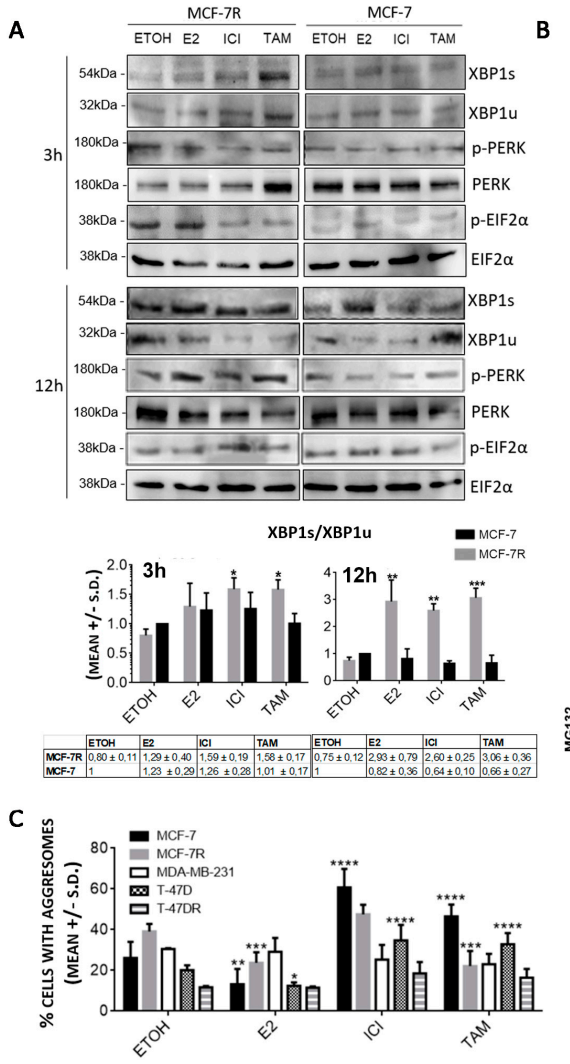
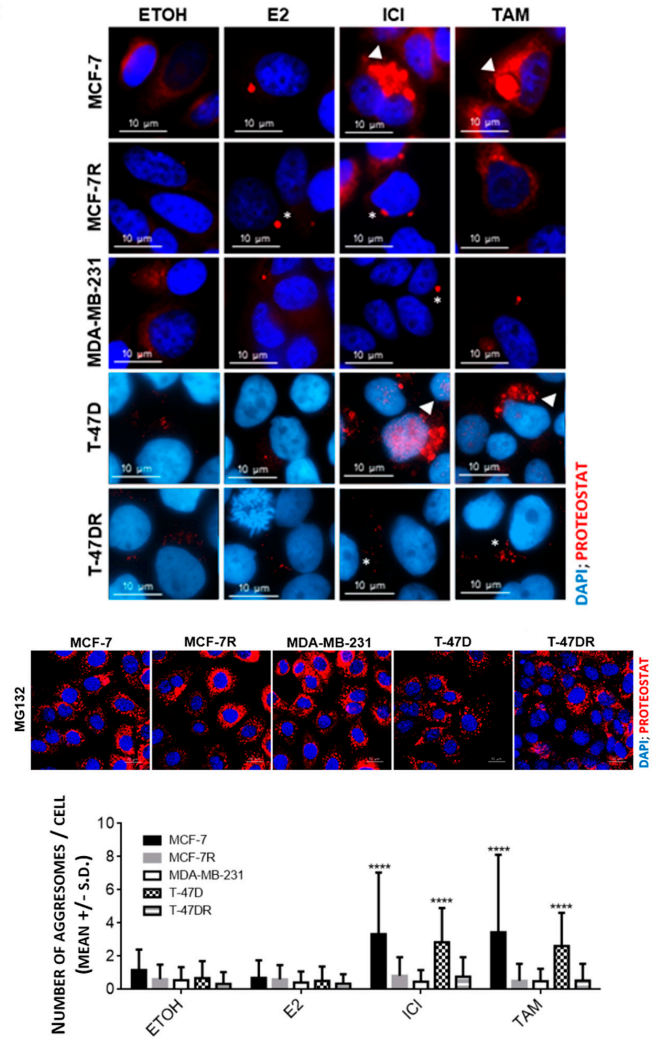

D
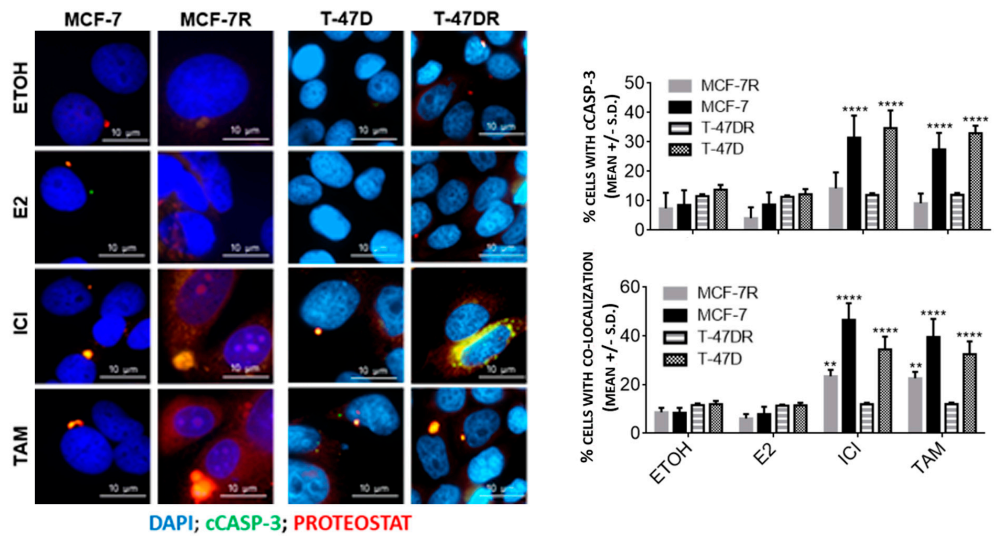

Figure 1. Characterization of antiestrogen-induced protein aggregation clearance and accumulation in breast cancer cell lines. (A) Western blot showing XBP1s/XBP1u ratio and activation of PERK/EIF2 $\alpha$ UPR branch after exposure to $10 \mathrm{nM} 17 \beta$-estradiol (E2), $250 \mathrm{nM}$ Fulvestrant (ICI) or $500 \mathrm{nM} 40 \mathrm{HO}$-tamoxifen (TAM). ${ }^{*} p<0.05 ;{ }^{* *} p<0.01 ;{ }^{* * *} p<0.001 \mathrm{vs}$. ETOH in the same cell line. Blots are representative of two experiments. (B) Comparative analysis of protein aggregation levels in MCF-7, MCF-7R, MDA-MB-231, T-47D and T-47DR cell lines. Staining with Proteostat ${ }^{\circledR}$ was carried out after $24 \mathrm{~h}$ treatment with $10 \mathrm{nM} \mathrm{E2,} 250 \mathrm{nM}$ ICI, $500 \mathrm{nM}$ TAM or $5 \mu \mathrm{M}$ MG132 (positive control for protein aggregation). Arrowheads: cytoplasmatic localization; star: juxtanuclear region. (C) The graphs summarize results from at least three independent experiments, as shown in (D), with a total of 10,000 cells counted. ${ }^{* * *} p<0.0001,{ }^{* * *} p<0.001,{ }^{* *} p<0.01$; vs. same cell line ETOH. D. Proteostat ${ }^{\circledR}$ and cleaved caspase-3 (cCASP-3) were colocalized by a double ICC after $24 \mathrm{~h}$ incubation with 10 nM E2, 250 nM ICI, 500 nM TAM. ${ }^{* * *} p<0.0001,{ }^{* *} p<0.01$ vs. same cell line ETOH. Representative of at least two experiments. In all cases, the cells received the same concentration of solvent (absolute ETOH). 


\begin{abstract}
3.2. Protein Aggregation after Antiestrogen Treatment Targets Different Pathways in Sensitive and Resistant Cells

To isolate protein aggregates for subsequent mass spectrometry analysis, we enriched in proteins that were insoluble in ionic detergent. These included intrinsically disordered proteins, like Amyloid A4 proteins and $\beta$-amyloids, which, using MG132, accumulate in Proteostat-stained aggresomes (Figure 2A). The detergent-insoluble and total protein fraction were separated by SDS-PAGE and exhibited an increased insoluble/total protein ratio (IF/T) only in antiestrogen-sensitive cells after treatment (Figure 2B,C). Notably, E2 protected proteins from detergent-induced destabilization, and the ER $\alpha$-negative MDAMB-231 cells did not exhibit increased levels of insoluble proteins (Figure 2B,C). The insoluble fractions of MCF-7 and MCF-7R cells were analyzed by LC-MS/MS to identify the pathways that could be hindered by loss of protein function due to aggregation. A total of 640 and 605 proteins were consistently found in the detergent-insoluble fraction of MCF-7 and MCF-7R cells, respectively. Treatment of MCF-7 cells with TAM or ICI for $24 \mathrm{~h}$ resulted in 38 proteins aggregated with TAM or ICI, 54 with TAM treatment and 22 with ICI (Figure 2D, top panel, and Table 1). For comparison, the unique proteins aggregated in MCF-7R cells after TAM or ICI treatment were also analyzed (Figure 2D, second from top, and Supplementary Table S2).
\end{abstract}

Table 1. Proteins found to be uniquely aggregated in MCF-7 cells following $24 \mathrm{~h}$ incubation with $4 \mathrm{OH}$-tamoxifen (TAM) or Fulvestrant (ICI).

\begin{tabular}{|c|c|c|c|}
\hline Uniprot IDs & Entry Name & Protein Name & Gene Names \\
\hline \multicolumn{4}{|c|}{ TAM } \\
\hline P42765 & THIM_HUMAN & 3-ketoacyl-CoA thiolase, mitochondrial & ACAA2 \\
\hline P22695 & QCR2_HUMAN & $\begin{array}{l}\text { Cytochrome b-c1 complex subunit } 2, \\
\text { mitochondrial }\end{array}$ & UQCRC2 \\
\hline Q9GZR7 & DDX24_HUMAN & ATP-dependent RNA helicase DDX24 & DDX24 \\
\hline P21926 & CD9_HUMAN & CD9 antigen & CD9 MIC3 TSPAN29 GIG2 \\
\hline O75607 & NPM3_HUMAN & Nucleoplasmin-3 & NPM3 \\
\hline Q96I24-1 & FUBP3_HUMAN & Far upstream element-binding protein 3 & FUBP3 FBP3 \\
\hline Q92552-2 & RT27_HUMAN & $28 \mathrm{~S}$ ribosomal protein $\mathrm{S} 27$, mitochondrial & MRPS27 KIAA0264 \\
\hline Q14974 & IMB1_HUMAN & Importin subunit beta-1 & KPNB1 NTF97 \\
\hline P46087-4 & NOP2_HUMAN & Probable $28 S$ rRNA & NOP2 NOL1 NSUN1 \\
\hline P07910-2 & HNRPC_HUMAN & $\begin{array}{l}\text { Heterogeneous nuclear ribonucleoproteins } \\
\qquad \mathrm{C} 1 / \mathrm{C} 2\end{array}$ & HNRNPC HNRPC \\
\hline Q9P0M6 & H2AW_HUMAN & Core histone macro-H2A.2 & MACROH2A2 H2AFY2 \\
\hline O00571 & DDX3X_HUMAN & ATP-dependent RNA helicase DDX3X & DDX3X DBX DDX3 \\
\hline P07741-1 & APT_HUMAN & Adenine phosphoribosyltransferase & APRT \\
\hline P31040 & SDHA_HUMAN & $\begin{array}{l}\text { Succinate dehydrogenase [ubiquinone] } \\
\text { flavoprotein subunit, mitochondrial }\end{array}$ & SDHA SDH2 SDHF \\
\hline O95793 & STAU1_HUMAN & $\begin{array}{l}\text { Double-stranded RNA-binding protein } \\
\text { Staufen homolog } 1\end{array}$ & STAU1 STAU \\
\hline Q8WXF1 & PSPC1_HUMAN & Paraspeckle component 1 & PSPC1 PSP1 \\
\hline P19338 & NUCL_HUMAN & Nucleolin & NCL \\
\hline
\end{tabular}


Table 1. Cont.

\begin{tabular}{|c|c|c|c|}
\hline Uniprot IDs & Entry Name & Protein Name & Gene Names \\
\hline P30041 & PRDX6_HUMAN & Peroxiredoxin-6 & PRDX6 AOP2 KIAA0106 \\
\hline Q5SSJ5-1 & HP1B3_HUMAN & $\begin{array}{l}\text { Heterochromatin protein 1-binding protein } \\
3\end{array}$ & HP1BP3 \\
\hline P52943-2 & CRIP2_HUMAN & Cysteine-rich protein 2 & CRIP2 CRP2 \\
\hline Q96DI7-2 & SNR40_HUMAN & $\begin{array}{l}\text { U5 small nuclear ribonucleoprotein } 40 \mathrm{kDa} \\
\text { protein }\end{array}$ & SNRNP40 PRP8BP SFP38 \\
\hline P06748 & NPM_HUMAN & Nucleophosmin & NPM1 NPM \\
\hline Q15233 & NONO_HUMAN & $\begin{array}{l}\text { Non-POU domain-containing } \\
\text { octamer-binding protein }\end{array}$ & NONO NRB54 \\
\hline P35659-1 & DEK_HUMAN & Protein DEK & DEK \\
\hline Q9HCD5 & NCOA5_HUMAN & Nuclear receptor coactivator 5 & NCOA5 KIAA1637 \\
\hline P62081 & RS7_HUMAN & $40 S$ ribosomal protein S7 & RPS7 \\
\hline Q12905 & ILF2_HUMAN & Interleukin enhancer-binding factor 2 & ILF2 NF45 PRO3063 \\
\hline Q9BTV4 & TMM43_HUMAN & Transmembrane protein 43 & TMEM43 UNQ2564/PRO6244 \\
\hline P09467 & F16P1_HUMAN & Fructose-1,6-bisphosphatase 1 & FBP1 FBP \\
\hline Q15084-2 & PDIA6_HUMAN & Protein disulfide-isomerase A6 & PDIA6 ERP5 P5 TXNDC7 \\
\hline O75367-1 & H2AY_HUMAN & Core histone macro-H2A.1 & MACROH2A1 H2AFY \\
\hline Q02543 & RL18A_HUMAN & $60 S$ ribosomal protein $\mathrm{L} 18 \mathrm{a}$ & RPL18A \\
\hline Q15427 & SF3B4_HUMAN & Splicing factor 3B subunit 4 & SF3B4 SAP49 \\
\hline P52597 & HNRPF_HUMAN & Heterogeneous nuclear ribonucleoprotein F & HNRNPF HNRPF \\
\hline Q96GQ7 & DDX27_HUMAN & $\begin{array}{l}\text { Probable ATP-dependent RNA helicase } \\
\text { DDX27 }\end{array}$ & DDX27 cPERP-F RHLP \\
\hline Q14651 & PLSI_HUMAN & Plastin-1 & PLS1 \\
\hline Q07065 & CKAP4_HUMAN & Cytoskeleton-associated protein 4 & CKAP4 \\
\hline Q9Y3I0 & RTCB_HUMAN & RNA-splicing ligase RtcB homolog & RTCB C22orf28 HSPC117 \\
\hline P46777 & RL5_HUMAN & $60 S$ ribosomal protein L5 & RPL5 MSTP030 \\
\hline Q9BQG0-2 & MBB1A_HUMAN & Myb-binding protein 1A & MYBBP1A P160 \\
\hline P12956 & XRCC6_HUMAN & X-ray repair cross-complementing protein 6 & XRCC6 G22P1 \\
\hline O60506 & HNRPQ_HUMAN & $\begin{array}{l}\text { Heterogeneous nuclear } \\
\text { ribonucleoprotein } \mathrm{Q}\end{array}$ & SYNCRIP HNRPQ NSAP1 \\
\hline Q9UBU9-1 & NXF1_HUMAN & Nuclear RNA export factor 1 & NXF1 TAP \\
\hline Q9UHX1-1 & PUF60_HUMAN & Poly(U)-binding-splicing factor PUF60 & PUF60 FIR ROBPI SIAHBP1 \\
\hline P13010 & XRCC5_HUMAN & X-ray repair cross-complementing protein 5 & XRCC5 G22P2 \\
\hline P22087 & FBRL_HUMAN & rRNA 2'-O-methyltransferase fibrillarin & FBL FIB1 FLRN \\
\hline Q9NP79 & VTA1_HUMAN & $\begin{array}{l}\text { Vacuolar protein sorting-associated protein } \\
\text { VTA1 homolog }\end{array}$ & $\begin{array}{l}\text { VTA1 C6orf55 HSPC228 } \\
\text { My012 }\end{array}$ \\
\hline O76021 & RL1D1_HUMAN & Ribosomal L1 domain-containing protein 1 & RSL1D1 CATX11 CSIG PBK1 \\
\hline P36578 & RL4_HUMAN & $60 S$ ribosomal protein $\mathrm{L} 4$ & RPL4 RPL1 \\
\hline P62269 & RS18_HUMAN & $40 S$ ribosomal protein S18 & RPS18 D6S218E \\
\hline
\end{tabular}


Table 1. Cont.

\begin{tabular}{|c|c|c|c|}
\hline Uniprot IDs & Entry Name & Protein Name & Gene Names \\
\hline P13804-1 & ETFA_HUMAN & $\begin{array}{l}\text { Electron transfer flavoprotein subunit } \\
\text { alpha, mitochondrial }\end{array}$ & ETFA \\
\hline O43390-1 & HNRPR_HUMAN & $\begin{array}{l}\text { Heterogeneous nuclear ribonucleoprotein } \\
\text { R }\end{array}$ & HNRNPR HNRPR \\
\hline P37837 & TALDO_HUMAN & Transaldolase & $\begin{array}{l}\text { TALDO1 TAL TALDO } \\
\text { TALDOR }\end{array}$ \\
\hline \multirow[t]{2}{*}{ P11387 } & TOP1_HUMAN & DNA topoisomerase 1 & TOP1 \\
\hline & & ICI & \\
\hline P27797 & CALR_HUMAN & Calreticulin & CALR CRTC \\
\hline P05386 & RLA1_HUMAN & $60 S$ acidic ribosomal protein $\mathrm{P} 1$ & RPLP1 RRP1 \\
\hline Q92499 & DDX1_HUMAN & ATP-dependent RNA helicase DDX1 & DDX1 \\
\hline Q13263 & TIF1B_HUMAN & Transcription intermediary factor 1-beta & TRIM28 KAP1 RNF96 TIF1B \\
\hline P50395-1 & GDIB_HUMAN & Rab GDP dissociation inhibitor beta & GDI2 RABGDIB \\
\hline P21266 & GSTM3_HUMAN & Glutathione S-transferase Mu 3 & GSTM3 GST5 \\
\hline P62847-4 & RS24_HUMAN & $40 S$ ribosomal protein $S 24$ & RPS24 \\
\hline P80404 & GABT_HUMAN & $\begin{array}{l}\text { 4-aminobutyrate aminotransferase, } \\
\text { mitochondrial }\end{array}$ & ABAT GABAT \\
\hline P21964-1 & COMT_HUMAN & Catechol O-methyltransferase & COMT \\
\hline Q16643-3 & DREB_HUMAN & Drebrin & DBN1 D0S117E \\
\hline Q14258 & TRI25_HUMAN & E3 ubiquitin/ISG15 ligase TRIM25 & TRIM25 EFP RNF147 ZNF147 \\
\hline P55060-1 & XPO2_HUMAN & Exportin-2 & CSE1L CAS XPO2 \\
\hline Q9UKD2 & MRT4_HUMAN & mRNA turnover protein 4 homolog & MRTO4 C1orf33 MRT4 \\
\hline P07237 & PDIA1_HUMAN & Protein disulfide-isomerase & P4HB ERBA2L PDI PDIA1 \\
\hline P07384 & CAN1_HUMAN & Calpain-1 catalytic subunit & CAPN1 CANPL1 PIG30 \\
\hline O94826 & TOM70_HUMAN & $\begin{array}{l}\text { Mitochondrial import receptor subunit } \\
\text { TOM70 }\end{array}$ & TOMM70 KIAA0719 TOM70 \\
\hline O75955 & FLOT1_HUMAN & Flotillin-1 & FLOT1 \\
\hline P62851 & RS25_HUMAN & $40 S$ ribosomal protein S25 & RPS25 \\
\hline P06396 & GELS_HUMAN & Gelsolin & GSN \\
\hline Q9UL46 & PSME2_HUMAN & Proteasome activator complex subunit 2 & PSME2 \\
\hline P13489 & RINI_HUMAN & Ribonuclease inhibitor & RNH1 PRI RNH \\
\hline \multirow[t]{2}{*}{ P22314 } & UBA1_HUMAN & $\begin{array}{l}\text { Ubiquitin-like modifier-activating } \\
\text { enzyme } 1\end{array}$ & UBA1 A1S9T UBE1 \\
\hline & & TAM or ICI & \\
\hline Q14257-2 & RCN2_HUMAN & Reticulocalbin-2 & RCN2 ERC55 \\
\hline P82979 & SARNP_HUMAN & SAP domain-containing ribonucleoprotein & SARNP HCC1 HSPC316 \\
\hline Q99873 & ANM1_HUMAN & Protein arginine N-methyltransferase 1 & $\begin{array}{l}\text { PRMT1 HMT2 HRMT1L2 } \\
\text { IR1B4 }\end{array}$ \\
\hline Q16181 & SEPT7_HUMAN & Septin-7 & SEPTIN7 CDC10 SEPT7 \\
\hline P41250 & GARS_HUMAN & Glycine-tRNA ligase & GARS1 GARS \\
\hline Q99832 & TCPH_HUMAN & T-complex protein 1 subunit beta & CCT7 CCTH NIP7-1 \\
\hline
\end{tabular}


Table 1. Cont.

\begin{tabular}{|c|c|c|c|}
\hline Uniprot IDs & Entry Name & Protein Name & Gene Names \\
\hline P17480-1 & UBF1_HUMAN & Nucleolar transcription factor 1 & UBTF UBF UBF1 \\
\hline P55735-1 & SEC13_HUMAN & Protein SEC13 homolog & SEC13 D3S1231E SEC13A \\
\hline Q96QR8 & PURB_HUMAN & Transcriptional activator protein Pur-beta & PURB \\
\hline P25787 & PSA2_HUMAN & Proteasome subunit alpha type-2 & PSMA2 HC3 PSC3 \\
\hline Q99497 & PARK7_HUMAN & Parkinson disease protein 7 & PARK7 \\
\hline Q08945 & SSRP1_HUMAN & FACT complex subunit SSRP1 & SSRP1 FACT80 \\
\hline P27824-2 & CALX_HUMAN & Calnexin & CANX \\
\hline P82650 & RT22_HUMAN & $28 \mathrm{~S}$ ribosomal protein S22, mitochondrial & MRPS22 C3orf5 RPMS22 \\
\hline P12532 & KCRU_HUMAN & Creatine kinase U-type, mitochondrial & CKMT1A CKMT; CKMT1B \\
\hline P31939 & PUR9_HUMAN & $\begin{array}{l}\text { Bifunctional purine biosynthesis protein } \\
\text { ATIC }\end{array}$ & ATIC PURH OK/SW-cl.86 \\
\hline Q6PJT7-1 & ZC3HE_HUMAN & $\begin{array}{l}\text { Zinc finger CCCH domain-containing } \\
\text { protein } 14\end{array}$ & $\mathrm{ZC} 3 \mathrm{H} 14$ \\
\hline Q9BVI4 & NOC4L_HUMAN & Nucleolar complex protein 4 homolog & NOC4L \\
\hline Q8WXX5 & DNJC9_HUMAN & DnaJ homolog subfamily C member 9 & DNAJC9 \\
\hline Q9NXF1 & TEX10_HUMAN & Testis-expressed protein 10 & TEX10 L18 Nbla10363 \\
\hline O60762 & DPM1_HUMAN & $\begin{array}{l}\text { Dolichol-phosphate mannosyltransferase } \\
\text { subunit } 1\end{array}$ & DPM1 \\
\hline Q16630-2 & CPSF6_HUMAN & $\begin{array}{l}\text { Cleavage and polyadenylation specificity } \\
\text { factor subunit } 6\end{array}$ & CPSF6 CFIM68 \\
\hline Q86UP2-1 & KTN1_HUMAN & Kinectin & KTN1 CG1 KIAA0004 \\
\hline P49591 & SYSC_HUMAN & Serine-tRNA ligase, cytoplasmic & SARS1 SARS SERS \\
\hline Q9UN86 & G3BP2_HUMAN & $\begin{array}{l}\text { Ras GTPase-activating protein-binding } \\
\text { protein } 2\end{array}$ & G3BP2 KIAA0660 \\
\hline Q96T37-1 & RBM15_HUMAN & RNA-binding protein 15 & RBM15 OTT OTT1 \\
\hline Q92530 & PSMF1_HUMAN & Proteasome inhibitor PI31 subunit & PSMF1 \\
\hline P23381 & SYWC_HUMAN & Tryptophan-tRNA ligase, cytoplasmic & WARS1 IFI53 WARS WRS \\
\hline Q8NE71-1 & ABCF1_HUMAN & $\begin{array}{l}\text { ATP-binding cassette sub-family F } \\
\text { member } 1\end{array}$ & ABCF1 ABC50 \\
\hline P61353 & RL27_HUMAN & $60 S$ ribosomal protein L27 & RPL27 \\
\hline P55084 & ECHB_HUMAN & $\begin{array}{l}\text { Trifunctional enzyme subunit beta, } \\
\text { mitochondrial }\end{array}$ & HADHB MSTP029 \\
\hline P09622 & DLDH_HUMAN & $\begin{array}{c}\text { Dihydrolipoyl dehydrogenase, } \\
\text { mitochondrial }\end{array}$ & DLD GCSL LAD PHE3 \\
\hline Q53GS9 & SNUT2_HUMAN & U4/U6.U5 tri-snRNP-associated protein 2 & USP39 CGI-21 HSPC332 \\
\hline P30101 & PDIA3_HUMAN & Protein disulfide-isomerase A3 & PDIA3 ERP57 ERP60 GRP58 \\
\hline O14579-1 & COPE_HUMAN & Coatomer subunit epsilon & COPE \\
\hline Q9UHB9 & SRP68_HUMAN & Signal recognition particle subunit SRP68 & SRP68 \\
\hline Q96EP5 & DAZP1_HUMAN & DAZ-associated protein 1 & DAZAP1 \\
\hline P17987 & TCPA_HUMAN & T-complex protein 1 subunit alpha & TCP1 CCT1 CCTA \\
\hline
\end{tabular}


A

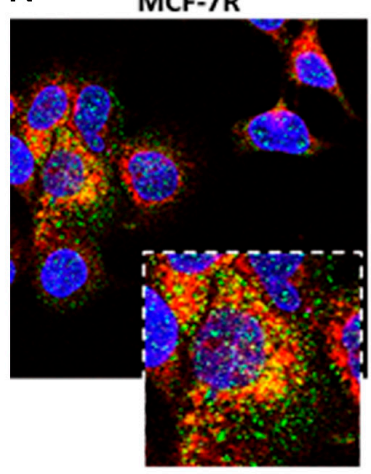

DAPI; PROTEOSTAT; $\beta$-AMYLOID
MCF-7

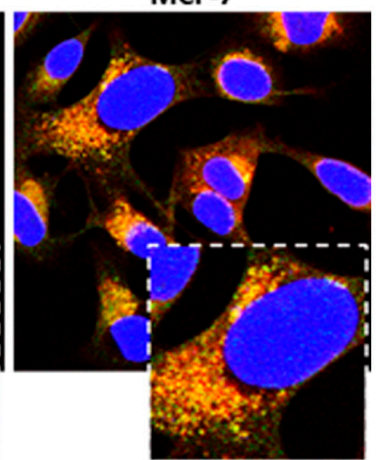

C
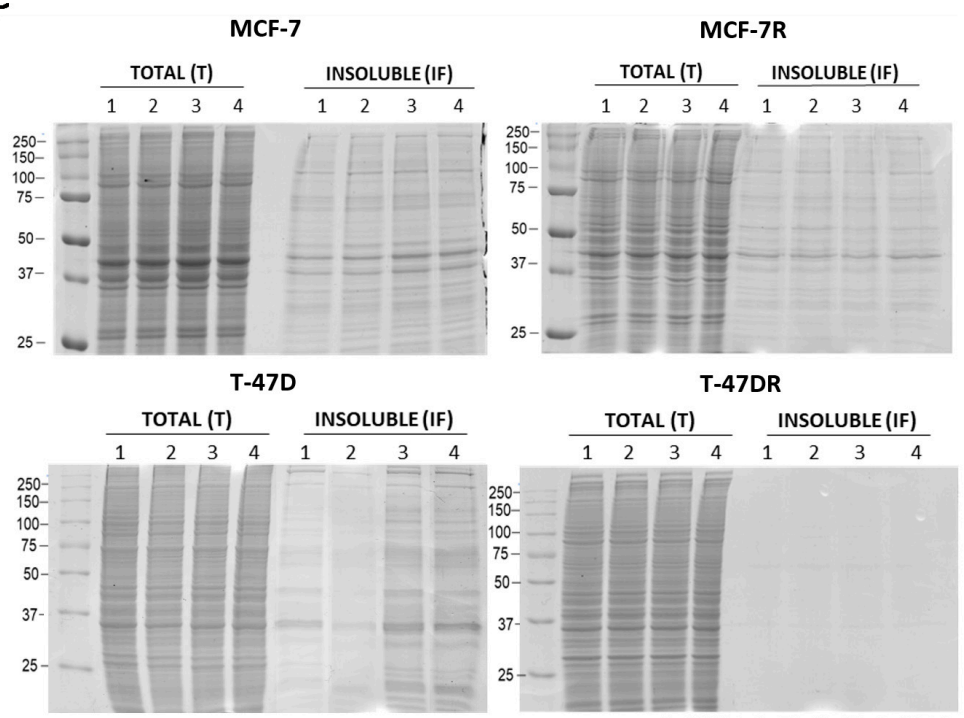

MDA-MB-231

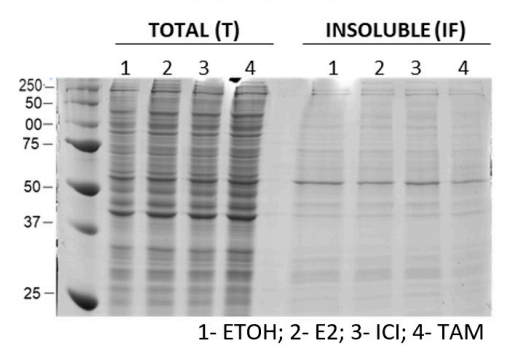

B

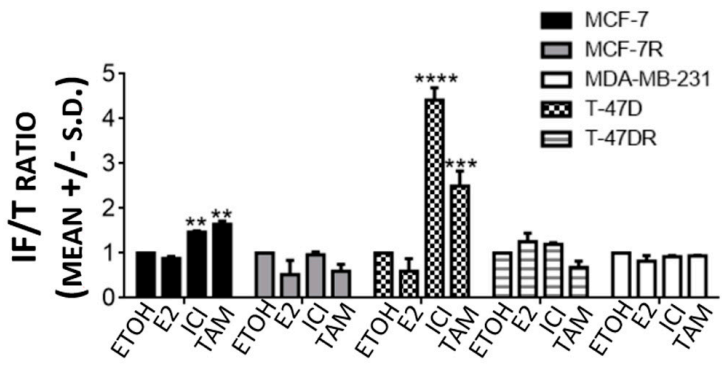

D
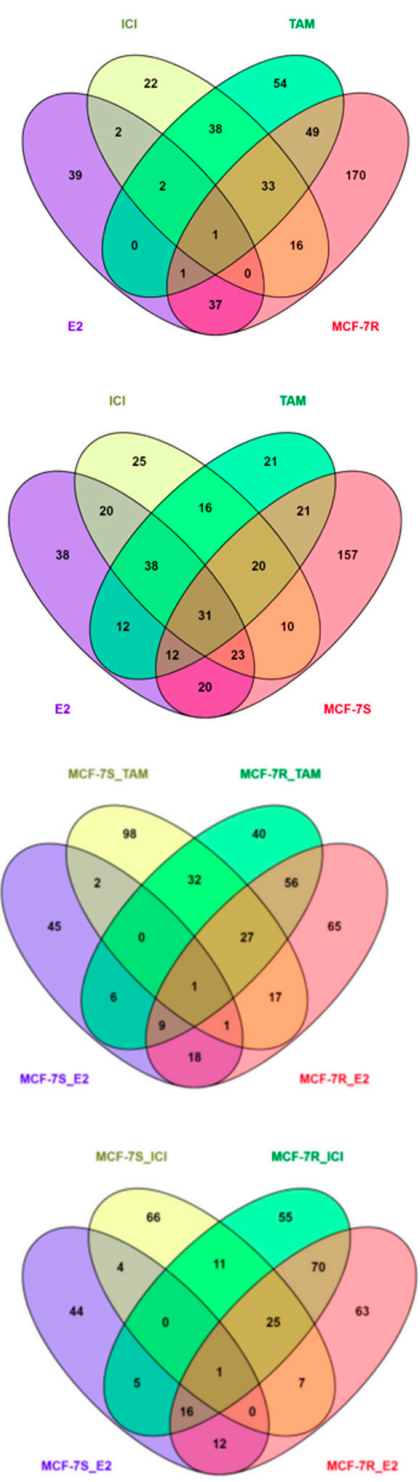

Figure 2. Characterization of aggregated proteins in breast cancer cells. (A) Confocal images of cells treated with $5 \mu \mathrm{M}$ MG132 for $24 \mathrm{~h}$ and co-stained with anti-Amyloid A4/ $\beta$-amyloid domain antibody and Proteostat ${ }^{\circledR}$. (B,C) SDS-PAGE resolution of total (T) and insoluble fractions (IFs) of antiestrogen-sensitive and resistant cells treated for $24 \mathrm{~h}$ with ETOH (control), $10 \mathrm{nM} \mathrm{E2,} 250 \mathrm{nM}$ ICI, $500 \mathrm{nM}$ TAM. ${ }^{* * *} p<0.0001,{ }^{* * *} p<0.001,{ }^{* *} p<0.01$ vs. same cell line ETOH, non-parametric $t$ test. (D) Venn diagrams showing the distribution of proteins identified by MS/MS as upregulated ( $>30 \% \mathrm{vs}$. ETOH) in the insoluble fraction of MCF-7 cells vs. the insoluble induced by E2, TAM or ICI in MCF-7R (top) and MCF-7R (bottom) vs. the insoluble induced by E2, TAM or ICI in MCF-7 cells. 
The aggregated proteins in MCF-7 cells significantly represented Proteasome pathway $\left(\mathrm{pTAM}=0.003\right.$ and $\mathrm{pICI}=7.03 \times 10^{-05} ;$ Table 2$)$. Additionally, TAM aggregated mRNA surveillance proteins $(p=0.015)$, while ICI targeted Protein processing in endoplasmic reticulum ( $p=0.027$ ). These pathways were not overrepresented by the detergent-insoluble proteins from MCF-7R after either TAM or ICI treatment. Instead, MCF-7R cells possessed detergent-insoluble proteins enriched in Huntington's disease ( $\mathrm{pICI}=0.002)$. We also identified proteins with relevance in proteinopathies in MCF-7 cells, including Poly(U)-bindingsplicing factor PUF60 (PUF60), associated with amyotrophic lateral sclerosis (ALS) [42-44], Transaldolase-1 (TALDO1), associated with Parkinson's disease [45], and hydroxyacyl-CoA dehydrogenase trifunctional multienzyme complex subunit beta (HADHB), related to Creutzfeldt-Jakob disease [46]. To rule out higher levels of detergent-insoluble proteins being a result of higher expression levels, we compared the 640 proteins found to be insoluble in MCF-7 cells with their values in the total protein extract and found no significant correlation (Spearman rTAM =0.019 and rICI = 0.13). Additionally, when analyzed individually, the total levels of the proteins found to be uniquely aggregated in MCF-7 cell after antiestrogen treatment were not up-regulated in the total protein fraction (Figure 3A).

Table 2. Kegg pathways represented by the aggregated proteins uniquely identified as upregulated in MCF-7 and MCF-7R cell lines after $24 \mathrm{~h}$ treatment with $250 \mathrm{nM}$ ICI or $500 \mathrm{nM}$ TAM.

\begin{tabular}{|c|c|c|c|c|}
\hline \multirow{2}{*}{$\frac{\text { MCF-7 }}{\text { Term }}$} & \multicolumn{2}{|c|}{ TAM } & \multicolumn{2}{|c|}{ ICI } \\
\hline & \# Proteins & $p$ Value & \# Proteins & $p$ Value \\
\hline hsa03010:Ribosome & 25 & $3.89 \times 10^{-19}$ & 6 & 0.011 \\
\hline hsa03040:Spliceosome & 23 & $5.88 \times 10^{-17}$ & 11 & $6.71 \times 10^{-7}$ \\
\hline hsa03015:mRNA surveillance pathway & 6 & 0.015 & & \\
\hline hsa03050:Proteasome & 4 & 0.033 & 6 & $7.03 \times 10^{-5}$ \\
\hline $\begin{array}{c}\text { hsa03008: Ribosome biogenesis in } \\
\text { eukaryotes }\end{array}$ & 5 & 0.050 & & \\
\hline hsa01130:Biosynthesis of antibiotics & 8 & 0.053 & & \\
\hline hsa03013:RNA transport & 7 & 0.057 & & \\
\hline hsa00020:Citrate cycle (TCA cycle) & 3 & 0.083 & & \\
\hline $\begin{array}{c}\text { hsa00280: Valine, leucine and isoleucine } \\
\text { degradation }\end{array}$ & & & 4 & 0.011 \\
\hline hsa01130:Biosynthesis of antibiotics & & & 7 & 0.019 \\
\hline $\begin{array}{l}\text { hsa04141:Protein processing in } \\
\text { endoplasmic reticulum }\end{array}$ & & & 6 & 0.027 \\
\hline $\begin{array}{c}\text { hsa04612:Antigen processing and } \\
\text { presentation }\end{array}$ & & & 4 & 0.040 \\
\hline MCF-7R & \multicolumn{2}{|c|}{ TAM } & \multicolumn{2}{|c|}{ ICI } \\
\hline Term & \# Proteins & $p$ Value & \# Proteins & $p$ Value \\
\hline hsa03010:Ribosome & 39 & $2.12 \times 10^{-39}$ & 17 & $1.17 \times 10^{-10}$ \\
\hline hsa03040:Spliceosome & 22 & $3.91 \times 10^{-16}$ & 29 & $2.10 \times 10^{-25}$ \\
\hline $\begin{array}{c}\text { hsa03008: Ribosome biogenesis in } \\
\text { eukaryotes }\end{array}$ & 5 & 0.045 & & \\
\hline hsa05168:Herpes simplex infection & 7 & 0.063 & 8 & 0.020 \\
\hline $\begin{array}{l}\text { hsa05412:Arrhythmogenic right } \\
\text { ventricular cardiomyopathy (ARVC) }\end{array}$ & 4 & 0.084 & & \\
\hline hsa05016:Huntington's disease & & & 10 & 0.002 \\
\hline
\end{tabular}


A

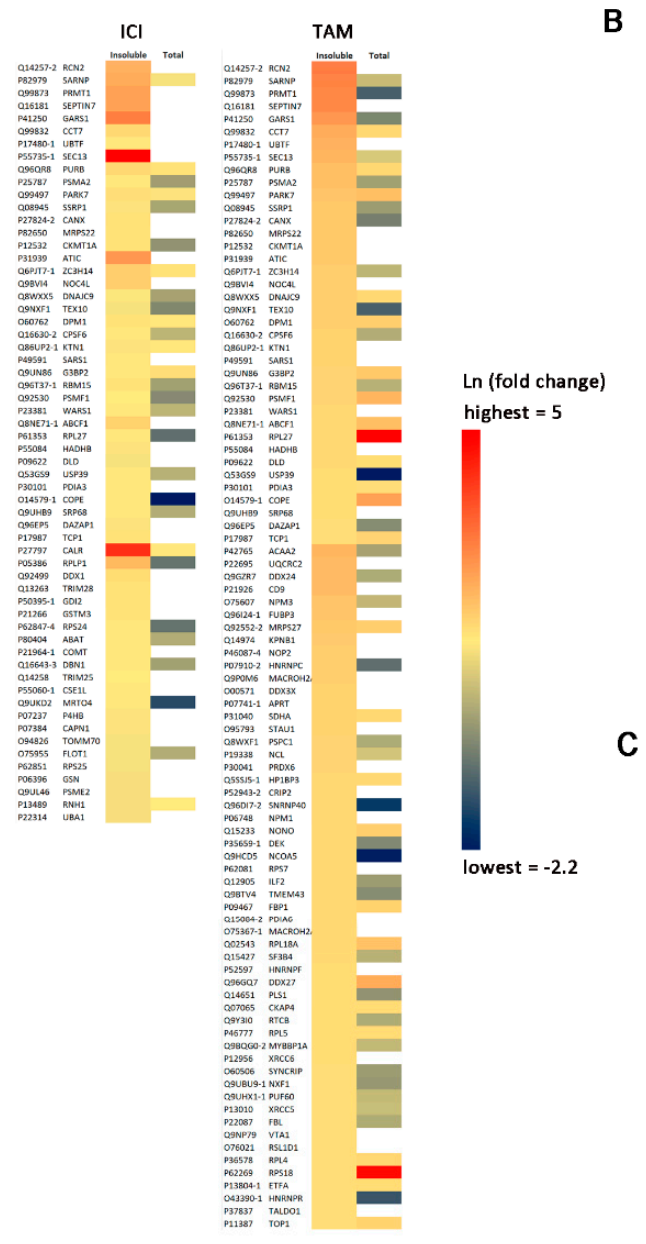

B

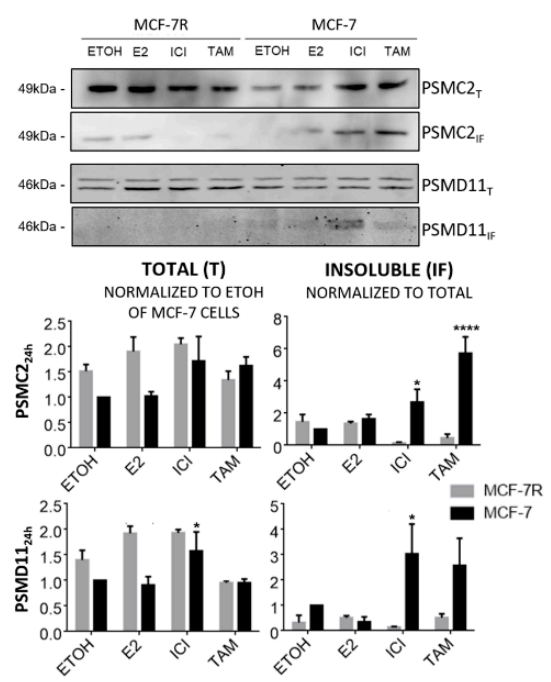

C
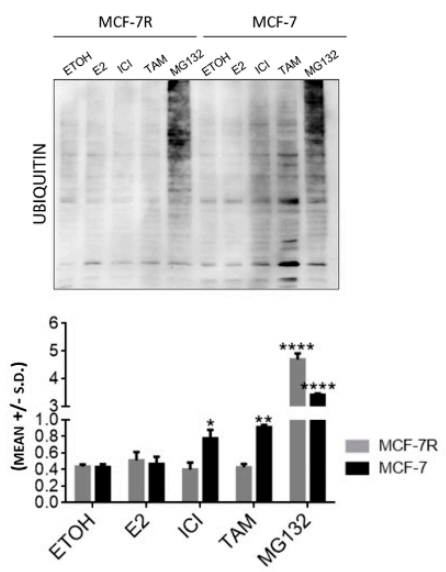

D
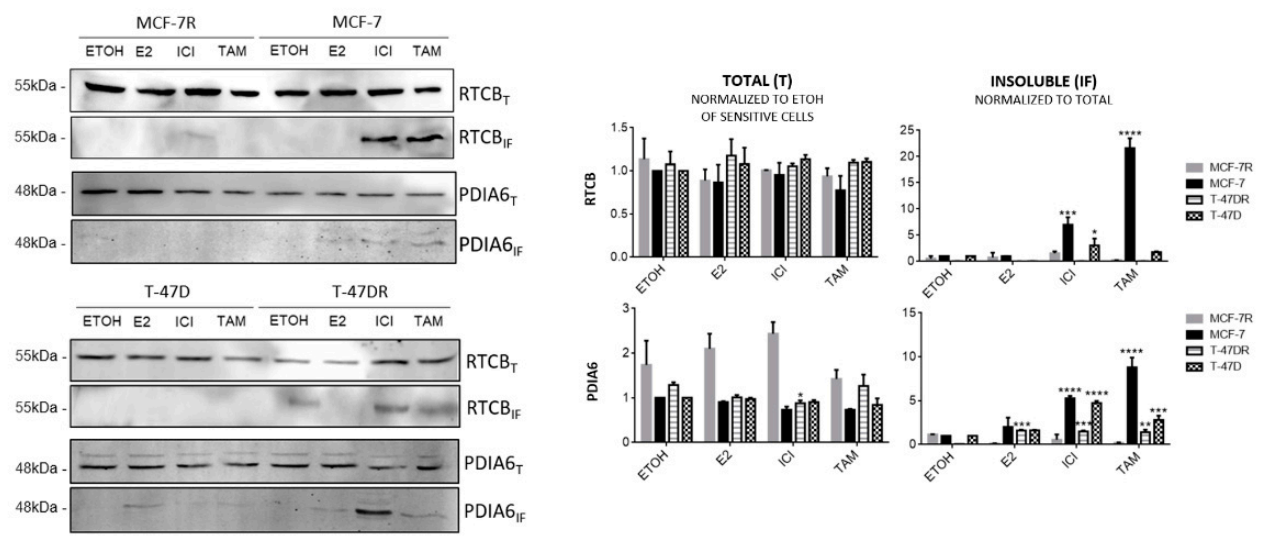

Figure 3. Protein aggregation induced by antiestrogens in MCF-7 cells. Cells were treated with $10 \mathrm{nM} \mathrm{E2,} 250 \mathrm{nM}$ ICI or $500 \mathrm{nM}$ TAM or the same volume of ETOH (control) for $24 \mathrm{~h}$. Total (T) and detergent-insoluble (IF) protein fractions were analyzed by LC-MS/MS or Western blot. (A) Heat map showing fold-change differences (cutoff $30 \%$ ) identified by LC-MS/MS. White spaces are proteins that were present in the insoluble fraction but not detected in the total protein fraction. (B) Western blot of total and insoluble PSMD11 and PSMC2. (C) Western blot showing total ubiquitin levels; $5 \mu \mathrm{M}$ MG132 was used as positive control. (D) Western blot of RTCB and PDIA6 and band intensity quantification. In all cases, results are representative of two experiments. ${ }^{* * *} p<0.0001,{ }^{* * *} p<0.001,{ }^{* *} p<0.01$ and ${ }^{*} p<0.05$ vs. ETOH in the same cell line, non-parametric $t$ test. 


\subsection{Protein Aggregation after Antiestrogen Treatment Impairs Proteasome and UPR Function}

Proteosome pathway proteins that consistently aggregated after TAM and ICI treatment where PSMC5 and PSMC4 in either MCF-7 or MCF-7R cells. PSMA2 and UBA1 were also only detected as aggregated in MCF-7 cells with either of the antiestrogens, with PSMD11 and PSMC2 mostly aggregated after ICI treatment (Table 1 and Supplementary Table S2). We confirmed using Western blot that even when aggregated in both sensitive and resistant cells lines, PSMD11 and PSMC2 were aggregated in higher levels in MCF7 cells (Figure 3B). Total levels of ubiquitinated proteins increased in MCF-7 cells after TAM or ICI treatment (Figure 3C), which strongly supports the notion that in sensitive cells, antiestrogens impair the proteasome function by inducing aggregation of several $26 \mathrm{~S}$ proteasome subunits.

RTCB and PDIA6 were also uniquely aggregated in MCF-7 cells (Figure 3D). RTCB catalyzes the ligation of XBP-1 mRNA following cleavage by IRE- $1 \alpha$ endonuclease [47], while PDIA6 maintains IRE- $1 \alpha$ activation within a physiologically acceptable range [48]. Total RTCB and PDIA6 did not change, although the insoluble proteins significantly increased only in MCF-7 and T-47D cells (Figure 3D). These results reinforce the idea that although RTCB and PDIA6 are expressed at similar levels in both sensitive and resistant cell lines, they are more prone to aggregation in sensitive cells in response to $\mathrm{ER} \alpha$ antagonism, which may lead to cytotoxicity due to their loss of function. In support of this idea, RTCB aggregation occurred already after 3h (Supplementary Figure S5A,B) and correlated with lack of XBP1s protein increase only in sensitive cells (Figure 1A). Moreover, RTCB subcellular localization is related to its dual function as t-RNA ligase (nuclear) [49] and XBP1 ligase (cytoplasm). We confirmed that in sensitive cells treated with antiestrogens, RTCB is initially localized in nuclear speckles but also in aggresomes, and after $24 \mathrm{~h}$, RTCB was mostly found in the aggresomes, while in resistant cells, RTCB did not colocalize with aggresomes (Supplementary Figure S5B). E2 treatment showed a clear RTCB distribution throughout the cytoplasm and nucleus of MCF-7 cells. As a control, we combined E2+TAM and evaluated the pattern of RTCB staining in relation to the aggresomes after $24 \mathrm{~h}$, where it was clear that addition of E2 did not prevent TAMmediated RTCB aggregation (Supplementary Figure S5C). Therefore, the RTCB instability triggered by antiestrogens in MCF-7 cells, impairs XBP1s-mediated proteostasis, promoting a vicious cycle of protein misfolding and aggresome accumulation.

\subsection{Inhibition of RTCB Expression Downregulates XBP1s and Improves Sensitivity to Tamoxifen}

To test whether RTCB function promotes survival to antiestrogens, we pre-treated MCF-7R cells with siRNAs to RTCB (siRTCB) for $24 \mathrm{~h}$, after which they were treated with TAM + siRTCB for an additional 3 days. siRTCB significantly decreased proliferation of TAM-treated cells (Figure 4A). The reversal of resistance to TAM was as efficient as the inhibition of proliferation observed in MCF-7 cells and was confirmed in T-47D/T-47DR cells. Moreover, similar to the IRE1 $\alpha$ inhibitor $4 \mu 8 \mathrm{C}$, RTCB reduced the XBP1s/XBP1u ratio (Figure $4 B, C$ ). In contrast to $4 \mu 8 C$, siRTCB downregulated BIP protein (Figure $4 B, C$ ), suggesting that blocking RTCB function may translate into longer lasting inhibition of UPR possibly due to the weak stability of the IRE1 $\alpha-4 \mu 8 \mathrm{C}$ complex [50]. Blocking XBP1s production by either siRTCB or $4 \mu 8 \mathrm{C}$ in MCF-7R treated with TAM resulted in increased aggresome formation and co-localization with cCASP-3 (Figure 4D). Interestingly, in siRTCB-treated cells, XBP1s and BIP levels were also reduced with $\mathrm{ETOH}$, but protein aggregation was only observed after challenging the cells with TAM, confirming that RTCB function supports resistance to TAM. 
A
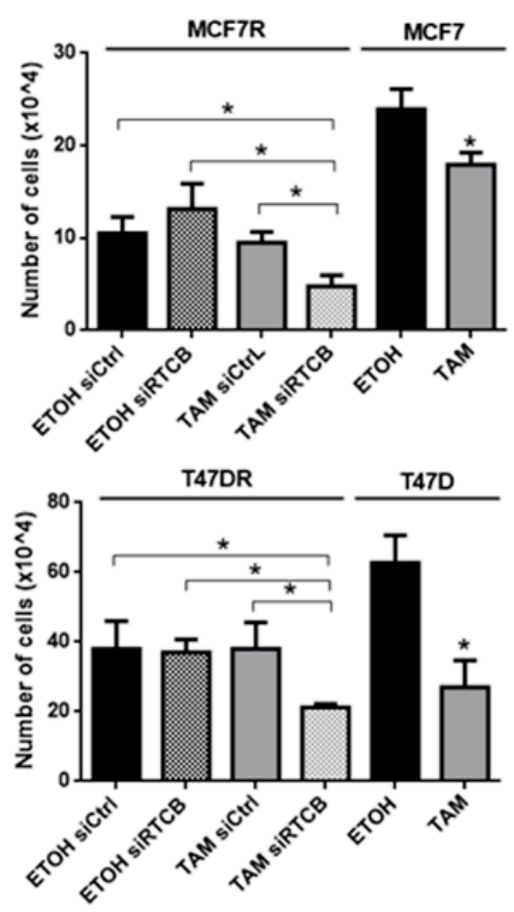

C

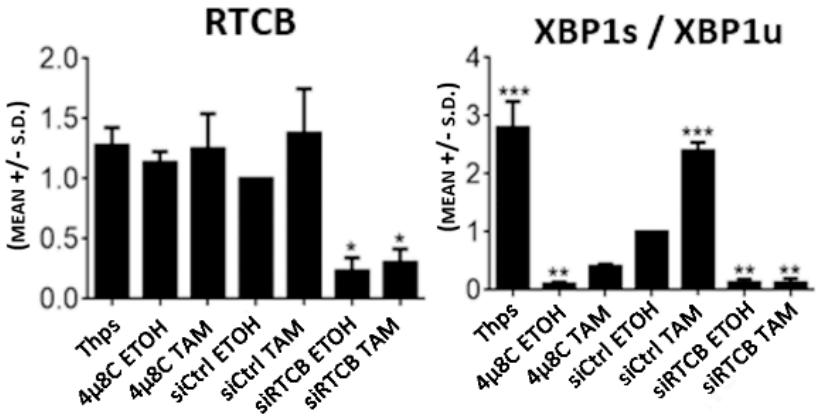

BIP

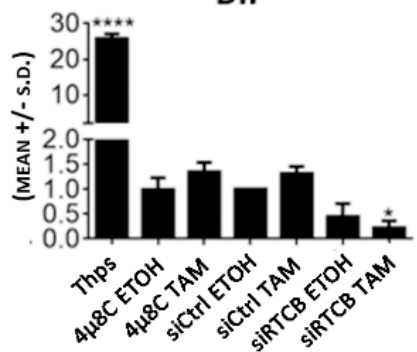

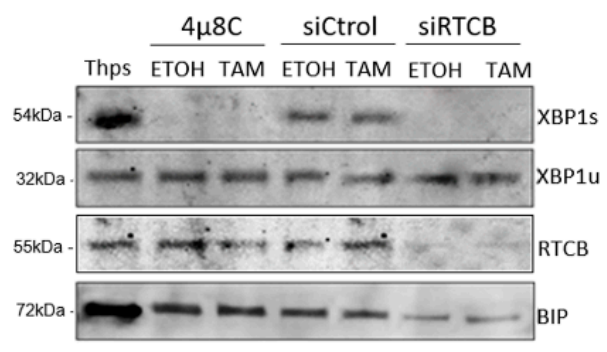

D
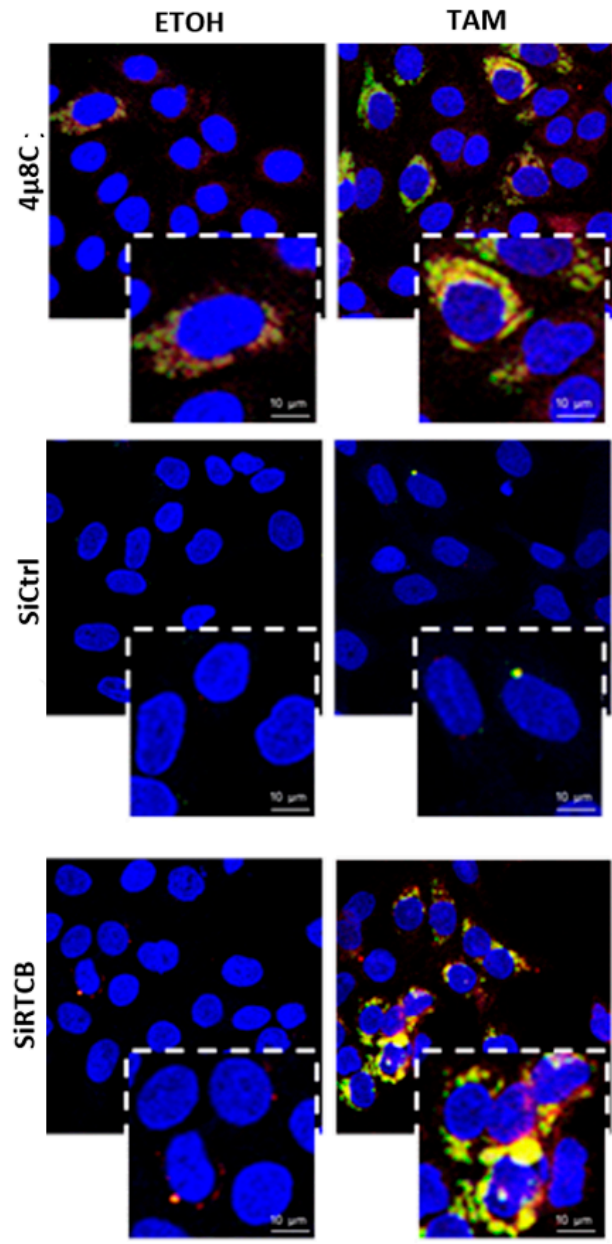

DAPI; CCASP-3; PROTEOSTAT

Figure 4. Inhibition of RTCB expression with siRNAs restores sensitivity to TAM in antiestrogen-resistant cell lines. (A) Knock-down of RTCB with siRNAs in MCF-7R and T-47DR cells for $24 \mathrm{~h}$ prior treatment with $500 \mathrm{nM}$ TAM + siRNAs for 3 days. Comparisons for the same cell line vs. other treatments, ${ }^{*} p<0.05$. Experiments are representative of three. (B) The effect of RTCB knock-down on XBP1s, XBP1u and BiP protein levels in MCF-7R cells was assessed and compared side-by-side to the effect of the IRE1 $\alpha$ activator Thapsigargin (Thps; $0.5 \mu \mathrm{M})$ and inhibitor $4 \mu 8 \mathrm{C}(25 \mu \mathrm{M})$. (C) Quantification of results shown in (B). Comparisons vs. siCtrl ETOH ${ }^{* * *}: p<0.001,{ }^{* *}: p<0.01^{*}: p<0.05,{ }^{* * * *}: p<0.0001$, non-parametric $t$ test. (D) Aggresome and cleaved CASP3 (cCASP-3) colocalization in cells treated for $24 \mathrm{~h}$ with 500nM TAM in combination with siRNA for RTCB or $25 \mu \mathrm{M} 4 \mu 8 \mathrm{C}$. 
To investigate the significance of RTCB aggregation in vivo, we tested a small cohort consisting of 22 paired samples of untreated primary tumor and the matched metastasis that appeared after completion of endocrine treatment (Supplementary Table S1). A statistically significant decrease in the percentage of cells with protein aggregates was found in metastatic tumors that represent disease recurrence after completion of endocrine treatment (Figure 5A). Aggregation of RTCB showed higher colocalization with aggresomes in the primary tumor as compared to the metastasis (Figure 5B). This supports the idea that protein aggregation in breast cancer tissue samples may provide information about tumor sensitivity to endocrine therapy and suggest that antiestrogen resistant cells are better capable of preventing RTCB aggregation.

A
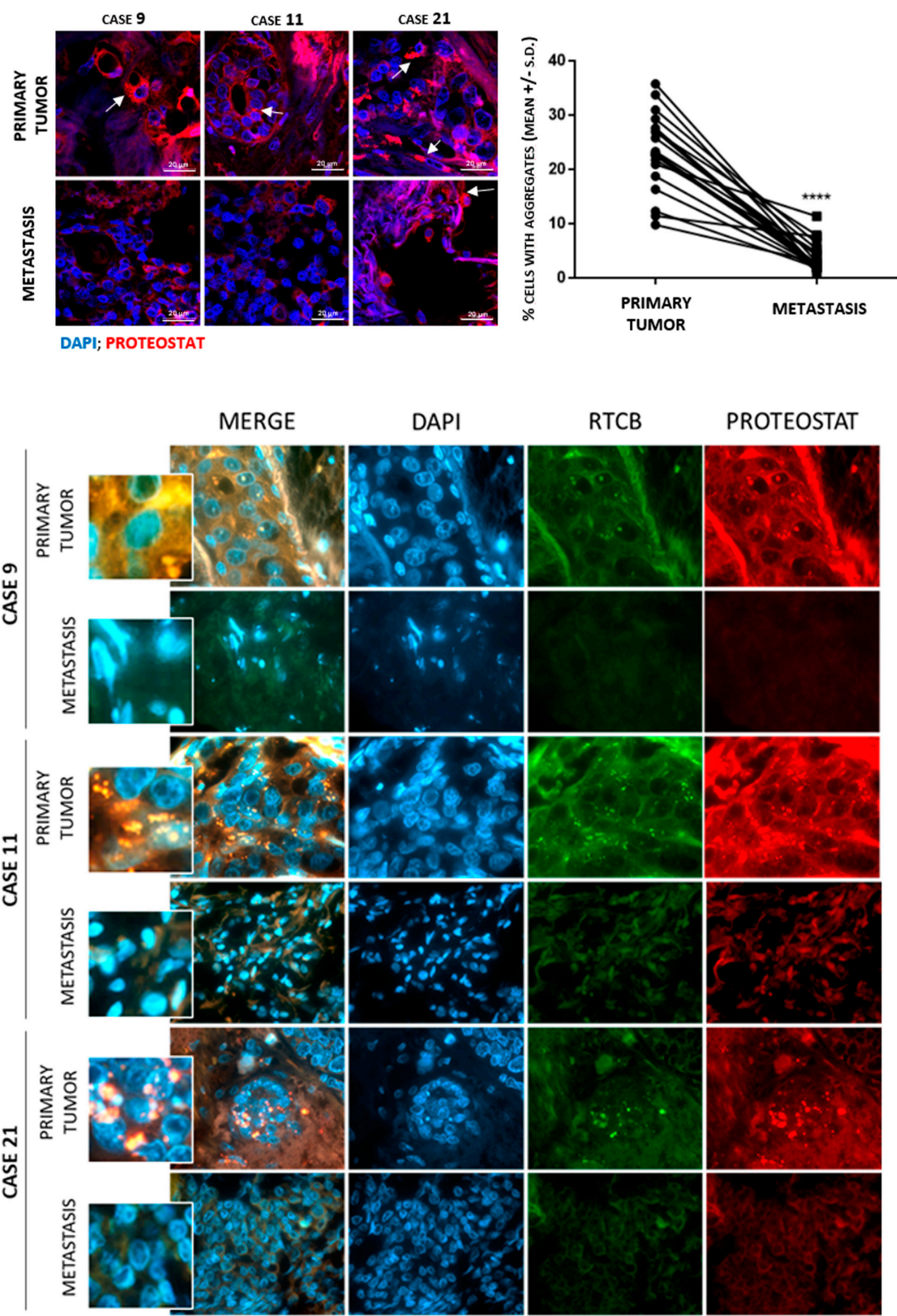

Figure 5. Protein aggregation levels and RTCB aggregation in luminal breast cancer. Human primary breast adenocarcinomas that were therapy naïve with their paired metastasis arising after completion of endocrine-therapy were analyzed by confocal microscopy. (A) Protein aggregation detected as aggresome accumulation using Proteostat ${ }^{\circledR}$. ${ }^{* * * *}: p<0.0001$; Wilcoxon test for paired samples. (B) Representative images of Proteostat ${ }^{\circledR}$ and RTCB co-localization. 


\section{Discussion}

Enhancement of UPR and autophagy have been linked to endocrine therapy resistance $[5,22]$. Our results go a step further, showing that antiestrogen treatment causes less aggresome accumulation in resistant cells due to maintenance of soluble/functional RTCB, needed to maintain the protective effect of IRE1 $\alpha /$ XBP1 pathway. Loss of RTCB function leads to aggresome accumulation, which can be used to predict antiestrogen response.

To date, the association of higher XBP1s with antiestrogen resistance had been related to co-activation of ER $\alpha$ by XBP-1s [51]. Here, we show that RTCB aggregation induced by antiestrogens and accumulation in aggresomes occurs only in sensitive cells and correlated with reduced XBP1s and BIP levels. Therefore, RTCB function could be targeted to revert endocrine resistance by reducing $\mathrm{ER} \alpha$ co-activation and protection from BIP chaperoning activity. We tested this hypothesis using RTCB knock-down in antiestrogen-resistant cells to demonstrate that RTCB loss of function reproduced the aggresome pattern of sensitive cells and re-sensitized to tamoxifen. Notably, RTCB knock-down produced a much more stable and powerful inhibition of the stress response mediated by XBP1s than the IRE1 $\alpha$ inhibitor $4 \mu 8 \mathrm{C}$, (measured as BiP protein levels). This may be because unfavorable pharmacokinetics limit the utility of $4 \mu 8 \mathrm{C}$ and other aldehydes that function as IRE1 $\alpha$ inhibitors [50]. Thus, RTCB targeting can potentially inhibit this pathway in a more stable manner.

Aggregated beta-amyloids are commonly found in proteinopathies [40] and have been associated with toxic gain of function through aberrant protein-protein interactions or loss of function [43,52]. Protein aggregates are known to remain insoluble in strong detergent buffers so, biochemical fractionation methods that involve the sequential use of buffers and detergents of increasing stringency and ultracentrifugation to separate the soluble and insoluble fractions have been applied to tissue and cellular homogenates [53-55]. The multistep protocol used in this study (Supplementary Figure S2) allows, at first, the separation of cytosolic soluble proteins and in a second phase, NP40 allows the solubilization and separation of membrane proteins. Additionally, as internal control, we were able to identify several proteins previously reported to be insoluble such as cytoskeletal proteins, collagens and matrix proteins [53] or with increased tendency to aggregate like TALDO1 [45], HADHB [46], TAR DNA-binding protein 43 (TDP-43) or PUF60 [42-44]. Interestingly, the number of aggregated proteins identified in the detergent-insoluble fraction of MCF-7 and MCF-7R cells was similar, although the identity and levels of specific proteins varied between the two phenotypes and did not correlate with total protein levels. This clearly shows that antiestrogens induce the aggregation of specific proteins. It has recently been shown that protein solubility increases when cells are undergoing cell division due to post-translational modifications regulating enzymatic activity [56]. In future studies it will be interesting to identify the stimuli that triggers this selective aggregation or protection of proteins.

Differential aggresome formation was found in therapy naïve primary luminal breast cancer vs. their metastasis, appearing after endocrine therapy. Only a small cohort was analyzed; however, the results are promising, as the metastases may have developed strategies to prevent RTCB aggregation. Future studies of luminal primary tumors from women that were treated with endocrine treatment, in which some developed early resistance/progression and others did not are needed. It is noteworthy that resistance to antiestrogens has been linked to emergence or selection of cancer stem-like cells [57,58]. There is an increasing body of evidence that points to important roles of UPR and autophagy in cancer stem-like subpopulaitons. Specifically, impairment of autophagy in breast cancer stem cells reduces expression of staminal markers, self-renewal capacity and tumorigenicity [59-61]. Autophagy is upregulated in mammospheres where Beclin1 and ATG4 are needed to maintain and expand the breas cancer stem-like populations [59,61,62]. UPR modulation in breast cancer stem-like cells has been less explored, yet it has been shown that BIP is enriched in these subpopulations isolated from multiple breast cancer cell lines [63] and activation of the IRE1/XBP1 branch was related to the maintenance breast cance stem cells, their tumorigenicity and resistance to chemotherapy $[64,65]$. Studies in 
other models have shown that damaged proteins are assymetrically partitioned during cell division [66-68]. Therefore, in the future, it will be interesting to explore whether protein aggregation load could function as a driving force for cancer stem-like features, through asymmetric partitioning and may explain the lack of protein aggregation in the metastasis arising after endocrine therapy.

In this work, we presented evidence concerning a new approach to identify antiestrogen response and disclosed RTCB as a novel player in controlling acquired antiestrogen resistance (Figure 6). Cell stress induced by antiestrogen treatment (i.e., induced by ROS or metabolic imbalances) $[69,70]$ results in protein misfolding. Since antiestrogen-sensitive cells have lower UPR and autophagic capacity [7,34], decreased proteasomal activity [71] and expression of chaperones [35,72], and the protein quality control mechanisms become saturated and aggresomes accumulate. Proteins trapped into aggresomes are essential to overcome proteotoxic stress (i.e., RTCB, proteasome proteins and chaperones) and their loss of function leads to a disruptive cycle of proteostasis loss leading to activation of apoptosis mediated by cCASP3 translocation to aggresomes. This is illustrated by the analysis of RTCB, which does not complete XBP1 splicing (dotted lines), and therefore, transcription of $\mathrm{XBP} 1 \mathrm{~s}$ target genes (i.e., BiP) is not activated. These alterations enhance EnR stress and may also decrease activation of ER $\alpha$-mediated proliferation by XBP1s [73]. On the other hand, proliferation and survival signaling remains active in resistant cells treated with antiestrogens. Since these cells have increased activation of their proteostasis mechanisms, misfolded proteins are easily cleared and since XBP1s are induced upon antiestrogen treatment, aggresome levels are kept low. In addition, co-activation of ER $\alpha$ by XBP1s may be possible, sustaining proliferation and survival. However, if RTCB is knocked-down in resistant-cells treated with antiestrogens, reduced levels of XBP1s are sufficient to promote aggresome accumulation and apoptosis.

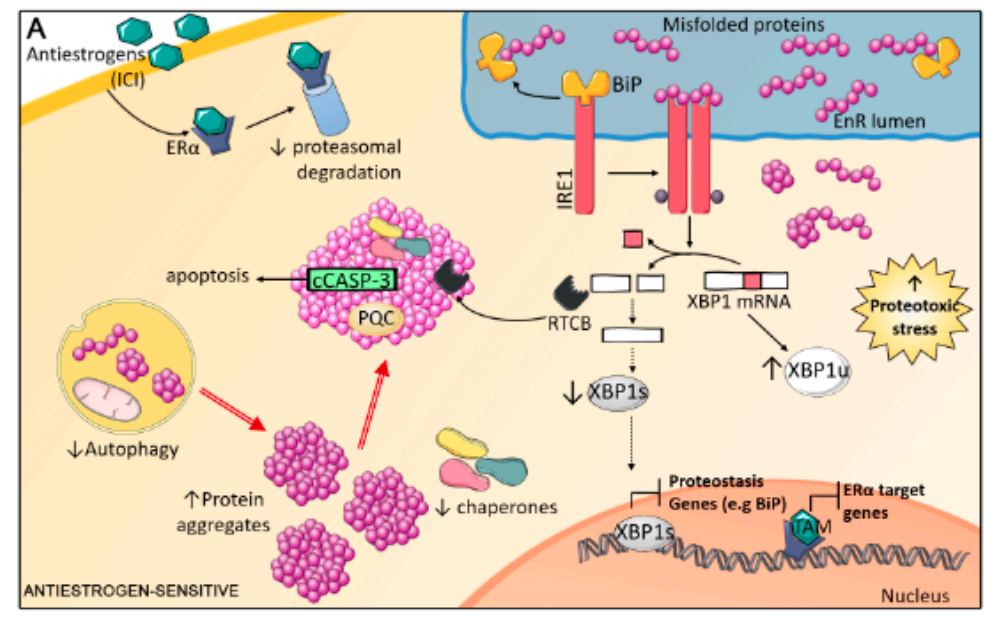

Figure 6. Cont. 


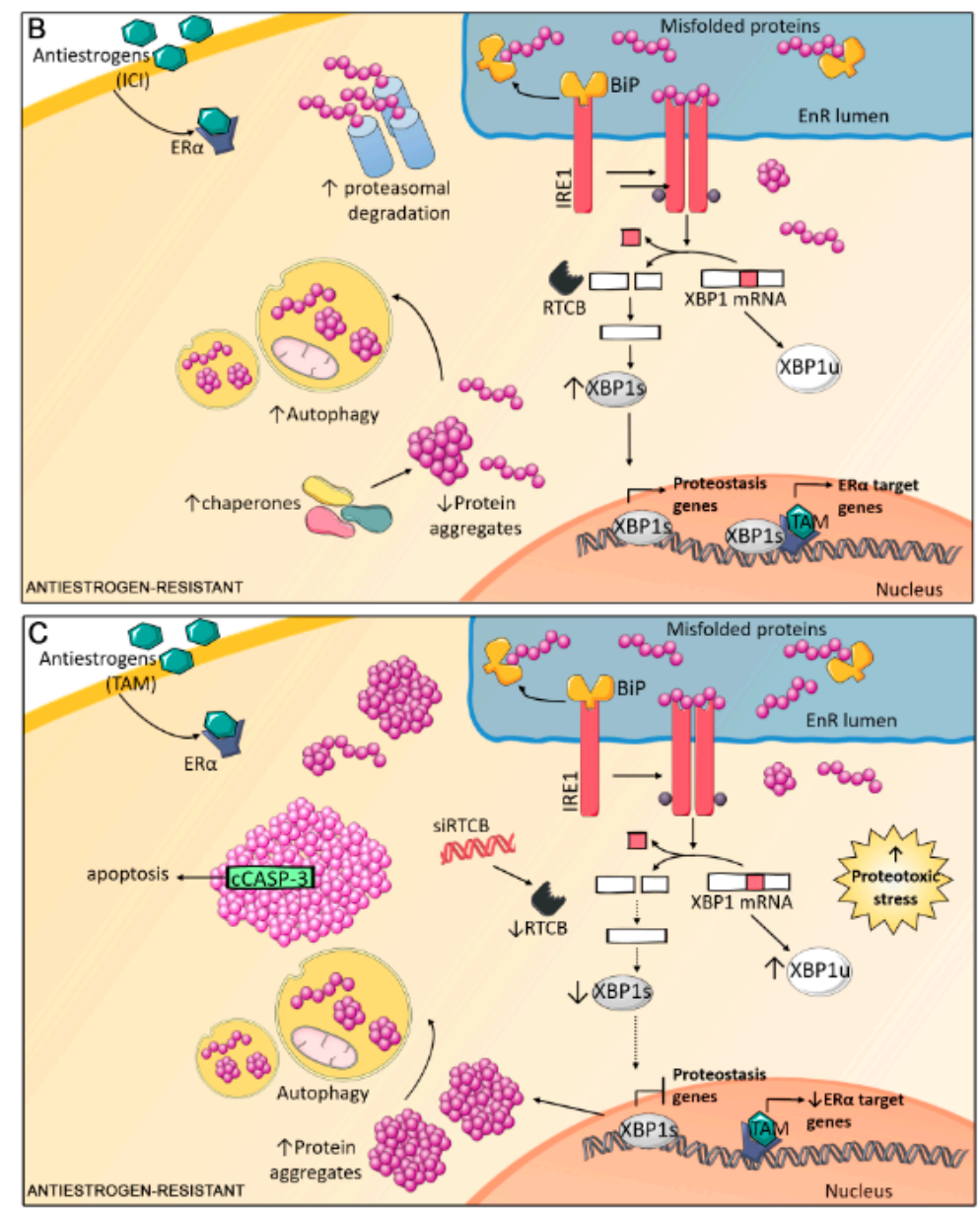

Figure 6. Schematic representation of the findings presented in this work in the context of previously described mechanisms guiding endocrine resistance. (A) In antiestrogen-sensitive cells, treatment with antiestrogens induces ER $\alpha$ proteasomal degradation (ICI) or inhibits the transcription of ER $\alpha$ target genes (TAM); consequently, proliferation and survival signaling is halted. Additionally, antiestrogen therapy increases oxidative and metabolic stress, which hinders correct protein folding to increase their aggregation. The results presented herein show that the PQC network (autophagy, UPR and proteasome) may be rapidly saturated leading to aggresome accumulation. Aggresomes contain essential proteins needed to overcome proteotoxic stress (i.e., RTCB, chaperones and PQC proteins), reducing their function. Aggregated RTCB cannot complete XBP1 splicing, XBP1 levels drop and, consequently, the activation of proteostasis genes under XBP1 regulation, like BiP, becomes compromised. Altogether, these events may generate a positive feedback loop increasing the accumulation of aggresomes which, in turn, potentiates the proteome instability and contributes to impair stress responses. Activation of pro-apoptotic pathways with co-localization of cleaved caspase 3 (cCASP-3) in aggresomes ultimately results in cellular death. (B) Antiestrogen-resistant cells have a higher autophagic and proteasomal degradation capacity, which, coupled with induced expression of XBP1s and transactivation of its target genes (i.e., BiP, chaperones, ERAD response) allows resistant cells to cope with protein misfolding and aggregation, keeping aggresome levels low. In addition, co-activation of ER $\alpha$ by XBP1s is possibly maintained, resulting in increased proliferation and treatment with antiestrogens do not compromise survival signaling. (C) RTCB knock-down in resistant cells treated with antiestrogens, results in impaired XBP1 expression which is sufficient to promote aggresome accumulation. Impaired transcription of proteostasis genes by XBP1s possibly contributes to saturate the PQC network. Intolerable proteome instability and consequent proteotoxic stress may activate pro-apoptotic pathways resulting in cellular death as observed by cCASP3 accumulation. EnR—endoplasmic reticulum; Era—estrogen receptor alpha; PQC—protein quality control proteins. 


\section{Conclusions}

Taken together, the findings presented herein suggest that protein aggregation patterns could be used to predict resistance to antiestrogen therapy, and they could be indicative of improved capacity to maintain a healthy proteome. This work opens a new avenue for research with respect to finding breast cancer prognostic markers and therapeutic targets, where the identification of proteins prone to aggregate could help identify antiestrogen response and understand mechanisms of disease.

Supplementary Materials: The following are available online at https:/ /www.mdpi.com/article/10 .3390 / cancers13133195/s1, Figure S1. Estrogen receptor expression and response to antiestrogenic treatment of MCF-7, MCF-7R, T-47D, T-47DR and MDA-MB-231 cell lines, Figure S2: Schematic representation of the insoluble fraction recovery protocol used in this study, Figure S3: Characterization of antiestrogen-induced protein aggregation clearance and accumulation in breast cancer cell lines, Figure S4: Correlation between autophagy activation and aggresome accumulation following antiestrogen treatment, Figure S5: Changes in RTCB expression levels in the total (T) and Insoluble Fractions (IF) of MCF-7 and MCF-7R cells along a period of 24h following ETOH (control), $10 \mathrm{nM}$ E2, $250 \mathrm{nM}$ ICI or $500 \mathrm{nM}$ TAM treatments, Table S1: Clinicopathological data of the patient cohort, Table S2: Proteins found uniquely aggregated in MCF-7R cells following $24 \mathrm{~h}$ incubation with 4OH-tamoxifen (TAM) or Fulvestrant (ICI). Full pictures of the Western blots are list in the supplementary materials.

Author Contributions: Conceptualization, L.A.H. and I.D.; methodology, I.D., L.M., T.M., J.L. and D.F.; formal analysis, I.D., L.M. and L.A.H.; investigation, I.D., L.M. and L.A.H.; resources, R.H., F.A., G.M., M.A.S.S., C.J. and M.F.; writing-original draft preparation, I.D. and L.A.H.; writing—review and editing, L.M., T.M., J.L., V.E., C.J., F.A. and M.F.; funding acquisition, M.A.S.S., M.F. and L.A.H. All authors have read and agreed to the published version of the manuscript.

Funding: This research was funded by national funds through FCT—Fundação para a Ciência e a Tecnologia—within the projects UID/BIM/04501/2013, UID/BIM/04501/2019, POCI-01-0145FEDER-007628 and UID/BIM/04501/2020, granted to the Aveiro Institute for Biomedicine. This work was also supported by the SR\&TD Integrated Programmes "pAGE-Protein aggregation Across the Lifespan" (CENTRO-01-0145-FEDER-000003) and by MEDISIS (CENTRO-01-0246-FEDER000018). Inês Direito, Liliana Monteiro and João Lobo are supported by the FCT PhD fellowships SFRH/BD/123821/2016, SFRH/BD/117818/2016 and SFRH/BD/132751/2017, respectively. Image acquisition was performed in the LiM facility of iBiMED, a node of PPBI (Portuguese Platform of BioImaging): POCI-01-0145-FEDER-022122.

Institutional Review Board Statement: The study was conducted according to the guidelines of the Declaration of Helsinki, and approved by the Ethics Committee of the PORTUGUESE ONCOLOGY INSTITUTE OF PORTO (protocol code CES IPO: 369/2017, date of approval: 14th December 2017).

Informed Consent Statement: Patient consent was waived due to the fact that only archival tissue was used exclusively in a retrospective way, obviating the need for patient consent according to Portuguese Law Art 19², n6, Law 12/2005 from January.

Data Availability Statement: The data presented in this study are available in the article and supplementary material.

Acknowledgments: We are grateful to Julia Gee for kindly providing the MCF-7R cell line. This does not imply Gee endorses the work.

Conflicts of Interest: The authors declare no conflict of interest.

\section{References}

1. Clarke, R.; Tyson, J.J.; Dixon, J.M. Endocrine resistance in breast cancer-An overview and update. Mol. Cell Endocrinol. 2015, 418, 220-234. [CrossRef] [PubMed]

2. Musgrove, E.A.; Sutherland, R.L. Biological determinants of endocrine resistance in breast cancer. Nat. Rev. Cancer 2009, 9, 631-643. [CrossRef] [PubMed]

3. Direito, I.; Fardilha, M.; Helguero, L.A. Contribution of the unfolded protein response to breast and prostate tissue homeostasis and its significance to cancer endocrine response. Carcinogenesis 2019, 40, 203-215. [CrossRef] 
4. Gomez, B.P.; Riggins, R.B.; Shajahan, A.N.; Klimach, U.; Wang, A.; Crawford, A.C.; Zhu, Y.; Zwart, A.; Wang, M.; Clarke, R. Human X-box binding protein-1 confers both estrogen independence and antiestrogen resistance in breast cancer cell lines. FASEB J. 2007, 21, 4013-4027. [CrossRef]

5. Davies, M.P.; Barraclough, D.L.; Stewart, C.; Joyce, K.A.; Eccles, R.M.; Barraclough, R.; Rudland, P.S.; Sibson, D.R. Expression and splicing of the unfolded protein response gene XBP-1 are significantly associated with clinical outcome of endocrine-treated breast cancer. Int. J. Cancer 2008, 123, 85-88. [CrossRef]

6. Ming, J.; Ruan, S.; Wang, M.; Ye, D.; Fan, N.; Meng, Q.; Tian, B.; Huang, T. A novel chemical, STF-083010, reverses tamoxifenrelated drug resistance in breast cancer by inhibiting IRE1/XBP1. Oncotarget 2015, 6, 40692-40703. [CrossRef] [PubMed]

7. Qadir, M.A.; Kwok, B.; Dragowska, W.H.; To, K.H.; Le, D.; Bally, M.B.; Gorski, S.M. Macroautophagy inhibition sensitizes tamoxifen-resistant breast cancer cells and enhances mitochondrial depolarization. Breast Cancer Res. Treat. 2008, 112, 389-403. [CrossRef] [PubMed]

8. Schoenlein, P.V.; Periyasamy-Thandavan, S.; Samaddar, J.S.; Jackson, W.H.; Barrett, J.T. Autophagy facilitates the progression of ERalpha-positive breast cancer cells to antiestrogen resistance. Autophagy 2009, 5, 400-403. [CrossRef]

9. Cook, K.L.; Shajahan, A.N.; Wärri, A.; Jin, L.; Hilakivi-Clarke, L.A.; Clarke, R. Glucose-regulated protein 78 controls cross-talk between apoptosis and autophagy to determine antiestrogen responsiveness. Cancer Res. 2012, 72, 3337-3349. [CrossRef]

10. Zhou, Y.; Rucker, E.B.; Zhou, B.P. Autophagy regulation in the development and treatment of breast cancer. Acta Biochim. Biophys. Sin. 2016, 48, 60-74. [CrossRef]

11. Voutsadakis, I.A. Proteasome expression and activity in cancer and cancer stem cells. Tumour Biol. 2017, 39 , 1010428317692248. [CrossRef]

12. Dubnikov, T.; Ben-Gedalya, T.; Cohen, E. Protein Quality Control in Health and Disease. Cold Spring Harb. Perspect. Biol. 2017, 9, a023523. [CrossRef] [PubMed]

13. Guang, M.H.Z.; Kavanagh, E.L.; Dunne, L.P.; Dowling, P.; Zhang, L.; Lindsay, S.; Bazou, D.; Goh, C.Y.; Hanley, C.; Bianchi, G.; et al. Targeting Proteotoxic Stress in Cancer: A Review of the Role that Protein Quality Control Pathways Play in Oncogenesis. Cancers 2019, 11, 66. [CrossRef]

14. Chen, X.; Cubillos-Ruiz, J.R. Endoplasmic reticulum stress signals in the tumour and its microenvironment. Nat. Rev. Cancer 2020, 21, 71-88. [CrossRef] [PubMed]

15. Hetz, C.; Chevet, E.; Harding, H.P. Targeting the unfolded protein response in disease. Nat. Rev. Drug Discov. 2013, 12, 703-719. [CrossRef] [PubMed]

16. Andruska, N.; Zheng, X.; Yang, X.; Helferich, W.G.; Shapiro, D.J. Anticipatory estrogen activation of the unfolded protein response is linked to cell proliferation and poor survival in estrogen receptor $\alpha$-positive breast cancer. Oncogene 2015, 34, 3760-3769. [CrossRef]

17. Uemura, A.; Oku, M.; Mori, K.; Yoshida, H. Unconventional splicing of XBP1 mRNA occurs in the cytoplasm during the mammalian unfolded protein response. J. Cell Sci. 2009, 122, 2877-2886. [CrossRef] [PubMed]

18. Popow, J.; Englert, M.; Weitzer, S.; Schleiffer, A.; Mierzwa, B.; Mechtler, K.; Trowitzsch, S.; Will, C.L.; Lührmann, R.; Söll, D.; et al. HSPC117 is the essential subunit of a human tRNA splicing ligase complex. Science 2011, 331, 760-764. [CrossRef]

19. Wang, D.Y.; Fulthorpe, R.; Liss, S.N.; Edwards, E.A. Identification of estrogen-responsive genes by complementary deoxyribonucleic acid microarray and characterization of a novel early estrogen-induced gene: EEIG1. Mol. Endocrinol. 2004, 18, 402-411. [CrossRef] [PubMed]

20. Li, H.; Chen, X.; Gao, Y.; Wu, J.; Zeng, F.; Song, F. XBP1 induces snail expression to promote epithelial- to-mesenchymal transition and invasion of breast cancer cells. Cell Signal. 2015, 27, 82-89. [CrossRef]

21. Crawford, A.C.; Riggins, R.B.; Shajahan, A.N.; Zwart, A.; Clarke, R. Co-inhibition of BCL-W and BCL2 restores antiestrogen sensitivity through BECN1 and promotes an autophagy-associated necrosis. PLoS ONE 2010, 5, e8604. [CrossRef] [PubMed]

22. Samaddar, J.S.; Gaddy, V.T.; Duplantier, J.; Thandavan, S.P.; Shah, M.; Smith, M.J.; Browning, D.; Rawson, J.; Smith, S.B.; Barrett, J.T.; et al. A role for macroautophagy in protection against 4-hydroxytamoxifen-induced cell death and the development of antiestrogen resistance. Mol. Cancer Ther. 2008, 7, 2977-2987. [CrossRef] [PubMed]

23. Groh, N.; Bühler, A.; Huang, C.; Li, K.W.; van Nierop, P.; Smit, A.B.; Fändrich, M.; Baumann, F.; David, D.C. Age-Dependent Protein Aggregation Initiates Amyloid- $\beta$ Aggregation. Front. Aging Neurosci. 2017, 9, 138. [CrossRef]

24. Vaquer-Alicea, J.; Diamond, M.I. Propagation of Protein Aggregation in Neurodegenerative Diseases. Annu. Rev. Biochem. 2019, 88, 785-810. [CrossRef]

25. Levy, C.B.; Stumbo, A.C.; Ano Bom, A.P.; Portari, E.A.; Cordeiro, Y.; Carneiro, Y.; Silva, J.L.; De Moura-Gallo, C.V. Co-localization of mutant p53 and amyloid-like protein aggregates in breast tumors. Int. J. Biochem. Cell Biol. 2011, 43, 60-64. [CrossRef] [PubMed]

26. Chiu, H.W.; Yeh, Y.L.; Ho, S.Y.; Wu, Y.H.; Wang, B.J.; Huang, W.J.; Ho, Y.S.; Wang, Y.J.; Chen, L.C.; Tu, S.H. A New Histone Deacetylase Inhibitor Enhances Radiation Sensitivity through the Induction of Misfolded Protein Aggregation and Autophagy in Triple-Negative Breast Cancer. Cancers 2019, 11, 1703. [CrossRef] [PubMed]

27. Shen, D.; Coleman, J.; Chan, E.; Nicholson, T.P.; Dai, L.; Sheppard, P.W.; Patton, W.F. Novel cell- and tissue-based assays for detecting misfolded and aggregated protein accumulation within aggresomes and inclusion bodies. Cell Biochem. Biophys. 2011, 60, 173-185. [CrossRef] 
28. Shevchenko, A.; Tomas, H.; Havlis, J.; Olsen, J.V.; Mann, M. In-gel digestion for mass spectrometric characterization of proteins and proteomes. Nat. Protoc. 2006, 1, 2856-2860. [CrossRef]

29. Oliveros, J.C. Venny. An Interactive Tool For Comparing Lists with Venn's Diagrams. 2007-2015. Available online: https: / / bioinfogp.cnb.csic.es/tools/venny/index.html (accessed on 13 May 2021).

30. Takalo, M.; Salminen, A.; Soininen, H.; Hiltunen, M.; Haapasalo, A. Protein aggregation and degradation mechanisms in neurodegenerative diseases. Am. J. Neurodegener Dis. 2013, 2, 1-14.

31. Kaganovich, D.; Kopito, R.; Frydman, J. Misfolded proteins partition between two distinct quality control compartments. Nature 2008, 454, 1088-1095. [CrossRef]

32. Ding, W.X.; Yin, X.M. Sorting, recognition and activation of the misfolded protein degradation pathways through macroautophagy and the proteasome. Autophagy 2008, 4, 141-150. [CrossRef] [PubMed]

33. Monaco, A.; Fraldi, A. Protein Aggregation and Dysfunction of Autophagy-Lysosomal Pathway: A Vicious Cycle in Lysosomal Storage Diseases. Front. Mol. Neurosci. 2020, 13, 37. [CrossRef]

34. Liu, J.; Yue, W.; Chen, H. The correlation between autophagy and tamoxifen resistance in breast cancer. Int. J. Clin. Exp. Pathol. 2019, 12, 2066-2074. [PubMed]

35. Parmar, J.H.; Cook, K.L.; Shajahan-Haq, A.N.; Clarke, P.A.; Tavassoly, I.; Clarke, R.; Tyson, J.J.; Baumann, W.T. Modelling the effect of GRP78 on anti-oestrogen sensitivity and resistance in breast cancer. Interface Focus 2013, 3, 20130012. [CrossRef]

36. Choi, K.S. Autophagy and cancer. Exp. Mol. Med. 2012, 44, 109-120. [CrossRef] [PubMed]

37. Bursch, W.; Ellinger, A.; Kienzl, H.; Török, L.; Pandey, S.; Sikorska, M.; Walker, R.; Hermann, R.S. Active cell death induced by the anti-estrogens tamoxifen and ICI 164384 in human mammary carcinoma cells (MCF-7) in culture: The role of autophagy. Carcinogenesis 1996, 17, 1595-1607. [CrossRef]

38. Cook, K.L.; Shajahan, A.N.; Clarke, R. Autophagy and endocrine resistance in breast cancer. Expert Rev. Anticancer Ther. 2011, 11, 1283-1294. [CrossRef]

39. Vera-Ramirez, L.; Vodnala, S.K.; Nini, R.; Hunter, K.W.; Green, J.E. Autophagy promotes the survival of dormant breast cancer cells and metastatic tumour recurrence. Nat. Commun. 2018, 9, 1944. [CrossRef]

40. Lotz, G.P.; Legleiter, J. The role of amyloidogenic protein oligomerization in neurodegenerative disease. J. Mol. Med. 2013, 91, 653-664. [CrossRef]

41. Shigemitsu, Y.; Hiroaki, H. Common molecular pathogenesis of disease-related intrinsically disordered proteins revealed by NMR analysis. J. Biochem. 2018, 163, 11-18. [CrossRef]

42. Guo, W.; Chen, Y.; Zhou, X.; Kar, A.; Ray, P.; Chen, X.; Rao, E.J.; Yang, M.; Ye, H.; Zhu, L.; et al. An ALS-associated mutation affecting TDP-43 enhances protein aggregation, fibril formation and neurotoxicity. Nat. Struct. Mol. Biol. 2011, 18, 822-830. [CrossRef]

43. Winton, M.J.; Igaz, L.M.; Wong, M.M.; Kwong, L.K.; Trojanowski, J.Q.; Lee, V.M. Disturbance of nuclear and cytoplasmic TAR DNA-binding protein (TDP-43) induces disease-like redistribution, sequestration, and aggregate formation. J. Biol. Chem. 2008, 283, 13302-13309. [CrossRef]

44. Tanikawa, C.; Ueda, K.; Suzuki, A.; Iida, A.; Nakamura, R.; Atsuta, N.; Tohnai, G.; Sobue, G.; Saichi, N.; Momozawa, Y.; et al. Citrullination of RGG Motifs in FET Proteins by PAD4 Regulates Protein Aggregation and ALS Susceptibility. Cell Rep. 2018, 22, 1473-1483. [CrossRef]

45. Monti, C.; Colugnat, I.; Lopiano, L.; Chiò, A.; Alberio, T. Network Analysis Identifies Disease-Specific Pathways for Parkinson's Disease. Mol. Neurobiol. 2018, 55, 370-381. [CrossRef]

46. Kipkorir, T.; Colangelo, C.M.; Manuelidis, L. Proteomic analysis of host brain components that bind to infectious particles in Creutzfeldt-Jakob disease. Proteomics 2015, 15, 2983-2998. [CrossRef]

47. Lu, Y.; Liang, F.X.; Wang, X. A synthetic biology approach identifies the mammalian UPR RNA ligase RtcB. Mol. Cell 2014, 55, 758-770. [CrossRef] [PubMed]

48. Eletto, D.; Dersh, D.; Gidalevitz, T.; Argon, Y. Protein disulfide isomerase A6 controls the decay of IRE1 $\alpha$ signaling via disulfidedependent association. Mol. Cell 2014, 53, 562-576. [CrossRef] [PubMed]

49. Pérez-González, A.; Pazo, A.; Navajas, R.; Ciordia, S.; Rodriguez-Frandsen, A.; Nieto, A. hCLE/C14orf166 associates with DDX1-HSPC117-FAM98B in a novel transcription-dependent shuttling RNA-transporting complex. PLoS ONE 2014, 9, e90957. [CrossRef] [PubMed]

50. Cross, B.C.; Bond, P.J.; Sadowski, P.G.; Jha, B.K.; Zak, J.; Goodman, J.M.; Silverman, R.H.; Neubert, T.A.; Baxendale, I.R.; Ron, D.; et al. The molecular basis for selective inhibition of unconventional mRNA splicing by an IRE1-binding small molecule. Proc. Natl. Acad. Sci. USA 2012, 109, E869-E878. [CrossRef] [PubMed]

51. Sengupta, S.; Sharma, C.G.; Jordan, V.C. Estrogen regulation of X-box binding protein-1 and its role in estrogen induced growth of breast and endometrial cancer cells. Horm. Mol. Biol. Clin. Investig. 2010, 2, 235-243. [CrossRef]

52. Winklhofer, K.F.; Tatzelt, J.; Haass, C. The two faces of protein misfolding: Gain- and loss-of-function in neurodegenerative diseases. EMBO J. 2008, 27, 336-349. [CrossRef] [PubMed]

53. David, D.C.; Ollikainen, N.; Trinidad, J.C.; Cary, M.P.; Burlingame, A.L.; Kenyon, C. Widespread protein aggregation as an inherent part of aging in C. elegans. PLoS Biol. 2010, 8, e1000450. [CrossRef] 
54. Gozal, Y.M.; Duong, D.M.; Gearing, M.; Cheng, D.; Hanfelt, J.J.; Funderburk, C.; Peng, J.; Lah, J.J.; Levey, A.I. Proteomics analysis reveals novel components in the detergent-insoluble subproteome in Alzheimer's disease. J. Proteome Res. 2009, 8, 5069-5079. [CrossRef]

55. Diner, I.; Nguyen, T.; Seyfried, N.T. Enrichment of Detergent-insoluble Protein Aggregates from Human Postmortem Brain. J. Vis. Exp. 2017, 128, 55835. [CrossRef]

56. Savitski, M.M.; Zinn, N.; Faelth-Savitski, M.; Poeckel, D.; Gade, S.; Becher, I.; Muelbaier, M.; Wagner, A.J.; Strohmer, K.; Werner, T.; et al. Multiplexed Proteome Dynamics Profiling Reveals Mechanisms Controlling Protein Homeostasis. Cell 2018, 173, 260-274.e25. [CrossRef]

57. Raffo, D.; Berardi, D.E.; Pontiggia, O.; Todaro, L.; de Kier Joffé, E.B.; Simian, M. Tamoxifen selects for breast cancer cells with mammosphere forming capacity and increased growth rate. Breast Cancer Res. Treat. 2013, 142, 537-548. [CrossRef] [PubMed]

58. O'Brien, C.S.; Farnie, G.; Howell, S.J.; Clarke, R.B. Are stem-like cells responsible for resistance to therapy in breast cancer? Breast Dis. 2008, 29, 83-89. [CrossRef]

59. Gong, C.; Bauvy, C.; Tonelli, G.; Yue, W.; Deloménie, C.; Nicolas, V.; Zhu, Y.; Domergue, V.; Marin-Esteban, V.; Tharinger, H.; et al. Beclin 1 and autophagy are required for the tumorigenicity of breast cancer stem-like/progenitor cells. Oncogene 2013, 32, 2261-2272. [CrossRef]

60. Chaterjee, M.; van Golen, K.L. Breast cancer stem cells survive periods of farnesyl-transferase inhibitor-induced dormancy by undergoing autophagy. Bone Marrow Res. 2011, 2011, 362938. [CrossRef]

61. Maycotte, P.; Jones, K.L.; Goodall, M.L.; Thorburn, J.; Thorburn, A. Autophagy Supports Breast Cancer Stem Cell Maintenance by Regulating IL6 Secretion. Mol. Cancer Res. 2015, 13, 651-658. [CrossRef] [PubMed]

62. Wolf, J.; Dewi, D.L.; Fredebohm, J.; Müller-Decker, K.; Flechtenmacher, C.; Hoheisel, J.D.; Boettcher, M. A mammosphere formation RNAi screen reveals that ATG4A promotes a breast cancer stem-like phenotype. Breast Cancer Res. 2013, 15, R109. [CrossRef] [PubMed]

63. Nami, B.; Ghasemi-Dizgah, A.; Vaseghi, A. Overexpression of molecular chaperons GRP78 and GRP94 in CD44(hi)/CD24(lo) breast cancer stem cells. Bioimpacts 2016, 6, 105-110. [CrossRef]

64. Chen, X.; Iliopoulos, D.; Zhang, Q.; Tang, Q.; Greenblatt, M.B.; Hatziapostolou, M.; Lim, E.; Tam, W.L.; Ni, M.; Chen, Y.; et al. XBP1 promotes triple-negative breast cancer by controlling the HIF1 $\alpha$ pathway. Nature 2014, 508, 103-107. [CrossRef]

65. Logue, S.E.; McGrath, E.P.; Cleary, P.; Greene, S.; Mnich, K.; Almanza, A.; Chevet, E.; Dwyer, R.M.; Oommen, A.; Legembre, P.; et al. Inhibition of IRE1 RNase activity modulates the tumor cell secretome and enhances response to chemotherapy. Nat. Commun. 2018, 9, 3267. [CrossRef] [PubMed]

66. Govers, S.K.; Mortier, J.; Adam, A.; Aertsen, A. Protein aggregates encode epigenetic memory of stressful encounters in individual Escherichia coli cells. PLoS Biol. 2018, 16, e2003853. [CrossRef]

67. Bufalino, M.R.; van der Kooy, D. The aggregation and inheritance of damaged proteins determines cell fate during mitosis. Cell Cycle 2014, 13, 1201-1207. [CrossRef] [PubMed]

68. Harvey, Z.H.; Chen, Y.; Jarosz, D.F. Protein-Based Inheritance: Epigenetics beyond the Chromosome. Mol. Cell 2018, 69, 195-202. [CrossRef]

69. Bekele, R.T.; Venkatraman, G.; Liu, R.Z.; Tang, X.; Mi, S.; Benesch, M.G.; Mackey, J.R.; Godbout, R.; Curtis, J.M.; McMullen, T.P.; et al. Oxidative stress contributes to the tamoxifen-induced killing of breast cancer cells: Implications for tamoxifen therapy and resistance. Sci. Rep. 2016, 6, 21164. [CrossRef]

70. Radde, B.N.; Ivanova, M.M.; Mai, H.X.; Alizadeh-Rad, N.; Piell, K.; Van Hoose, P.; Cole, M.P.; Muluhngwi, P.; Kalbfleisch, T.S.; Rouchka, E.C.; et al. Nuclear respiratory factor-1 and bioenergetics in tamoxifen-resistant breast cancer cells. Exp. Cell Res. 2016, 347, 222-231. [CrossRef]

71. Okumura, T.; Ikeda, K.; Ujihira, T.; Okamoto, K.; Horie-Inoue, K.; Takeda, S.; Inoue, S. Proteasome 26S subunit PSMD1 regulates breast cancer cell growth through p53 protein degradation. J. Biochem. 2018, 163, 19-29. [CrossRef]

72. Whitesell, L.; Santagata, S.; Mendillo, M.L.; Lin, N.U.; Proia, D.A.; Lindquist, S. HSP90 empowers evolution of resistance to hormonal therapy in human breast cancer models. Proc. Natl. Acad. Sci. USA 2014, 111, 18297-18302. [CrossRef] [PubMed]

73. Ding, L.; Yan, J.; Zhu, J.; Zhong, H.; Lu, Q.; Wang, Z.; Huang, C.; Ye, Q. Ligand-independent activation of estrogen receptor alpha by XBP-1. Nucleic Acids Res. 2003, 31, 5266-5274. [CrossRef] [PubMed] 